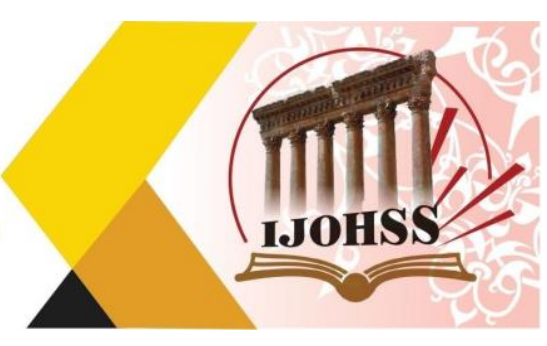

\title{
حسين مروة ونشاطه السياسي والثقافي في العراق (1949-1908)
}

\author{
م.د. سلمان رشيّ محمد الهرلالي

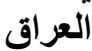

البريد الاكتروني: gmail.com

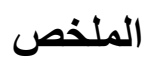

البحث هو استعر اض تاريخي لسيرة المنظر الماركسي اللبناني حسين مروة ونشاطه السياسي والثقافي خلال فترته العر اقية التي استمرت خمسة وعثرين عاما (1924-1949) ـ وينقسم البحث الى ثنلاث محاور رئيسية

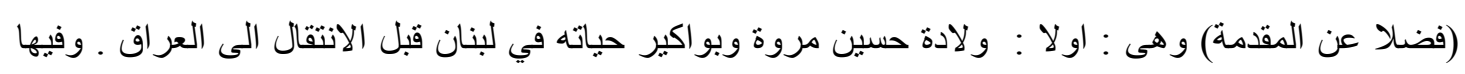
استعر اض الاصول العائلية وعلاقته مع و الده الثيخ علي مروة وتاثير وفاته المفاجئة عليه ودر استه الاولية في المدارس التقليدية و العصرية في جنوب لبنان ـ و الثاني ، اختص بحياة حسين مروة في العر اق ودر استه الدينية

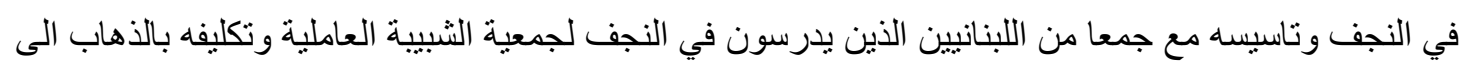
مدينة العمارة لمواجهة حركة التبشير المسيحي البروتستانتي القائمة انذاك وتأثره بالفكر الماركسي من خلال الاطلاع على البيان الثيوعي وتركه الدراسة الدينية ونزعه اللباس الديني وتعينه مدرسا في الناصرية وبغداد النياد ومشاركته الفاعلة بالاحداث السياسية التي اكتنفت الو اقع العر اقي انذاك و اسقاط الجنسية العر اقية عنه عام 1949 وترحيله الى لبنان ـ و الثالث، اهتم بالنشاط الثقافي لحسين مروة في العر اق مستعرضا لنماذج من كتاباته الصحفية

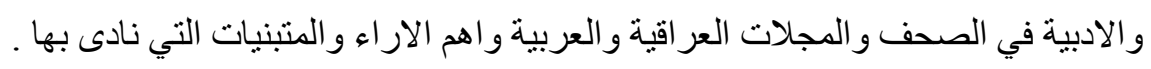
الكلمات المفتاحية: حسين مروة ، الحركة الثقافية في العراق . 


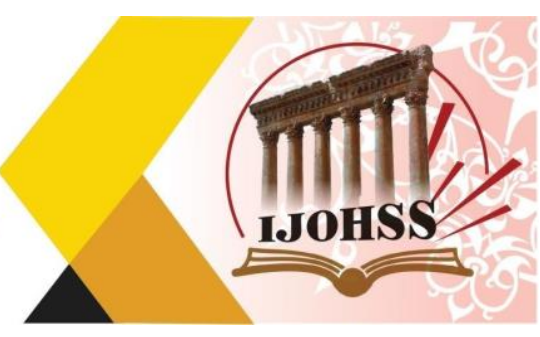

\title{
Hussein Marwa and his Political and Cultural Activity in Iraq (1908-1949)
}

\author{
Dr. Salman Rashid Muhammad Al-Hilali \\ Dhi Qar Education Directorate - Ministry of Education \\ Iraq \\ Email: abw34229@gmail.com
}

\begin{abstract}
This research is a historical review of the history of the Lebanese Marxist theorist Hussein Marwa and his political and cultural activity during his staying in Iraq which lasts twenty-five years (1924-1949). The research is divided into three main sections (as well as the introduction): First: the birth of Hussein Marwa and his life in Lebanon before moving to Iraq. In which the origins of his family has been reviewd, his relationship with his father Sheikh Ali Marwa as well as the impact of his sudden death and his initial studies in traditional and modern schools in southern Lebanon. The second section was devoted to the life of Hussein Marwa in Iraq, his religious studies in Najaf and his establishment, with a group of Lebanese studying in Najaf, for the international Youth Society. He was assigned to go to Amara to confront the christian Protestant missionary movement and was influenced by the Marxist thoughts when he read the Communist Manifesto. He was appointed a teacher in Nasiriyah and Baghdad and his active participation in the political events that characterized the Iraqi reality at the time and the overthrow of Iraqi nationality from him in 1949 and his deportation to Lebanon. And the third section was about in the cultural activity of Hussein Marwa in Iraq, reviewing examples of his writings and literary literature in the Iraqi and Arabic newspapers and magazines and the most important opinions that he called for.
\end{abstract}

Keywords: Hussein Marwa, Cultural Activity in Iraq. 


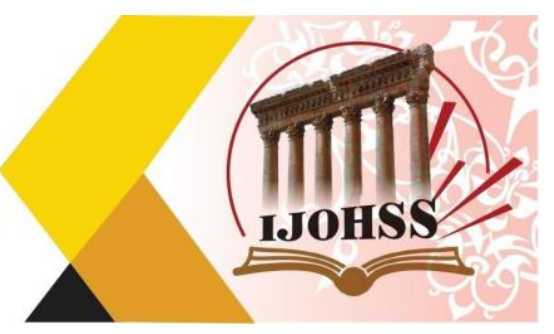

المقدمة

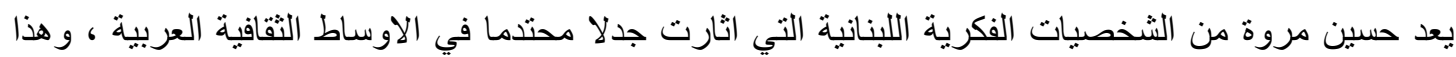

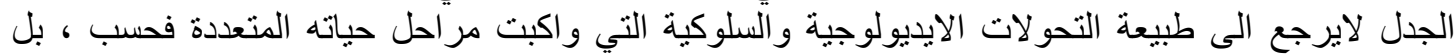

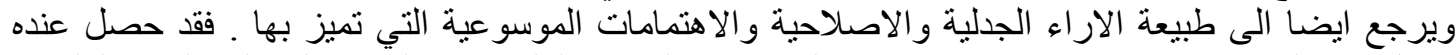

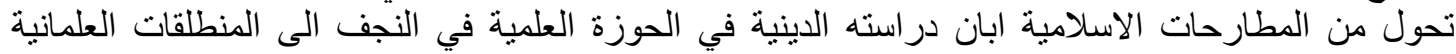

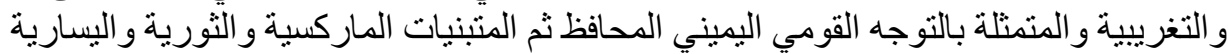

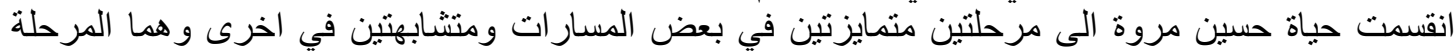

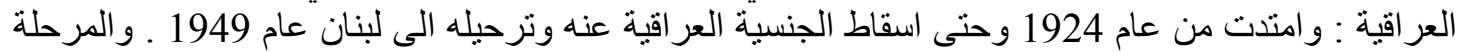

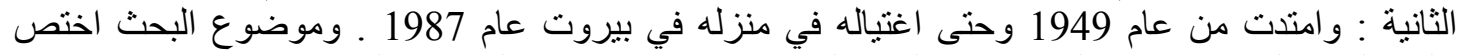

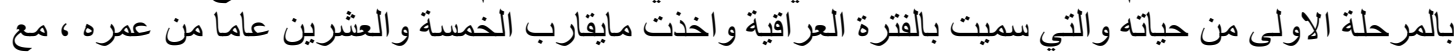

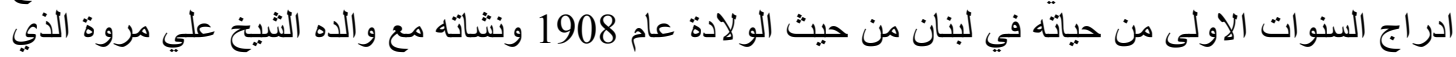

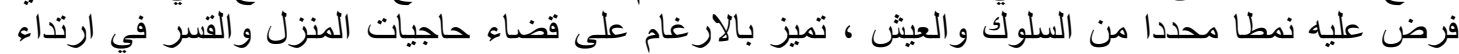

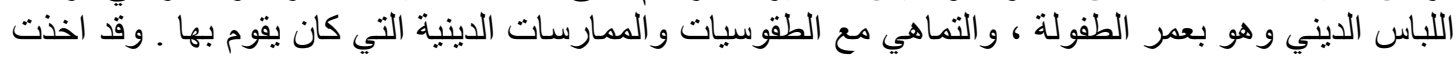

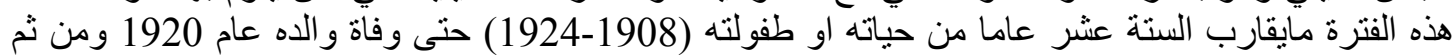

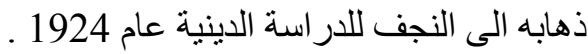

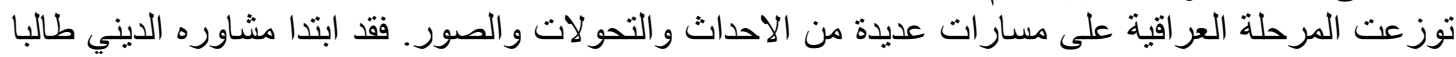

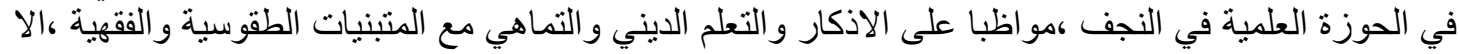

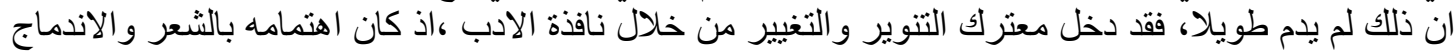

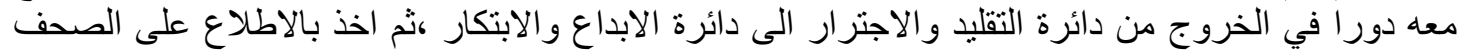

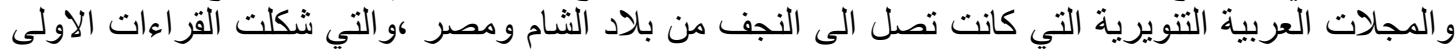

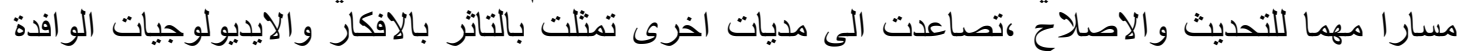

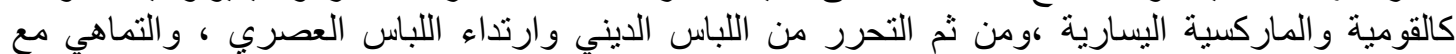

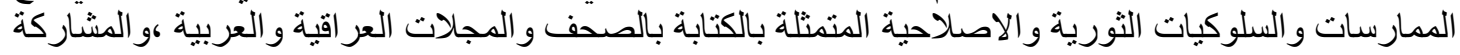

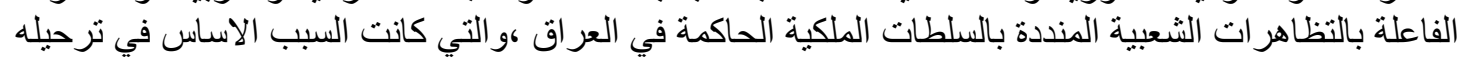

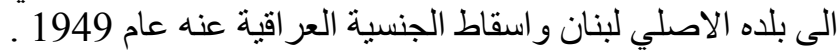

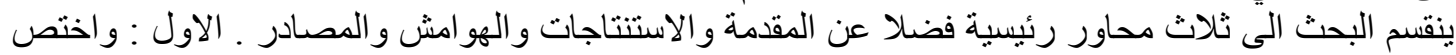

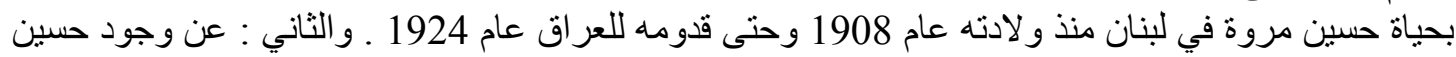

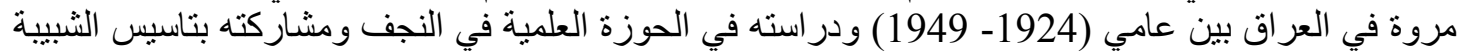

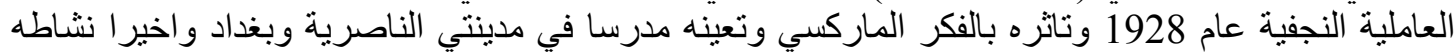

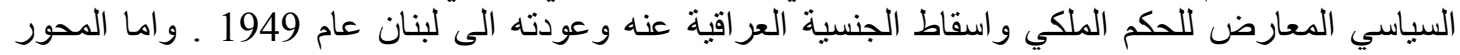
الثالث و الاخير فقد اختص بالنشاط الثقافي لحسين مروة في العر اق وكتاباته وقصائده ومقالاته الثان .

اولا : حسين مروة : ولادته ونشاته في لبنان 1908 - 1924

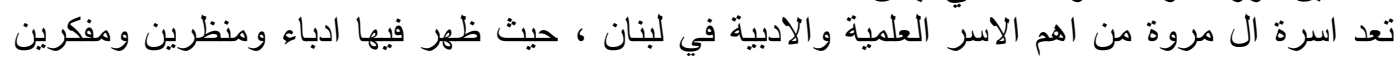

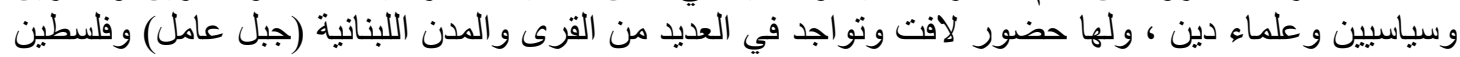

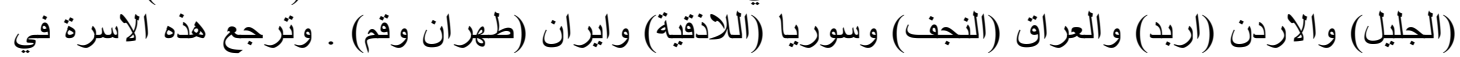

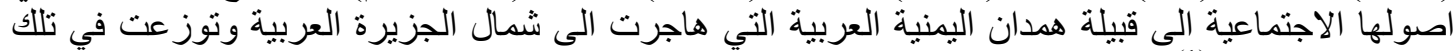
الاماكن الحضارية (1) الاجنية

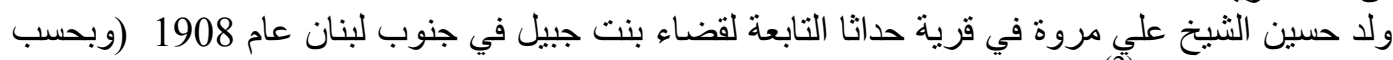

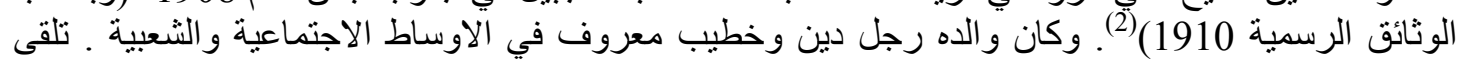

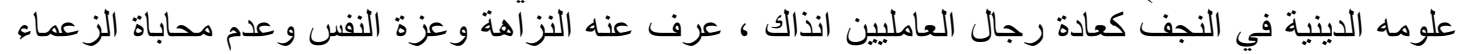

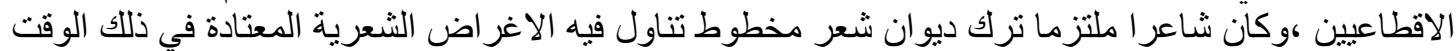

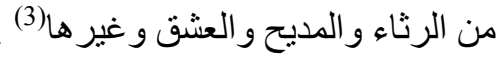




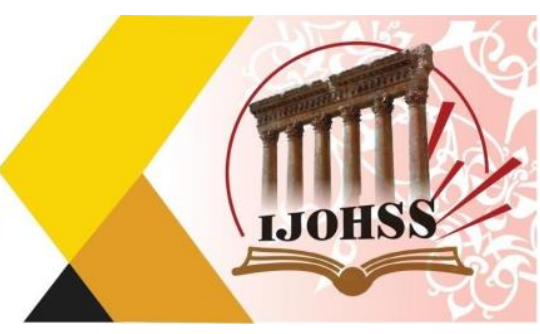

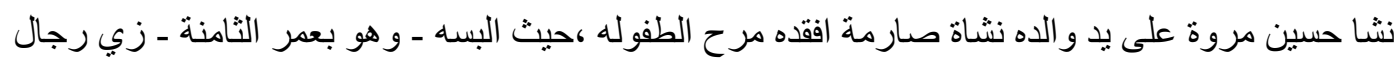

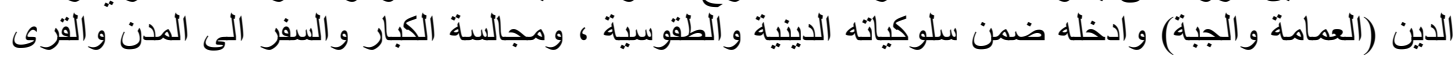

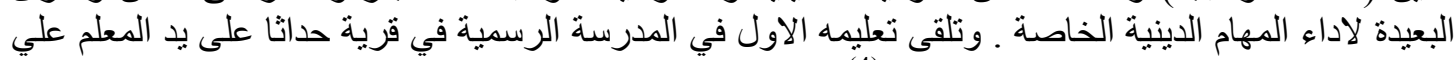

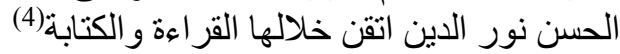

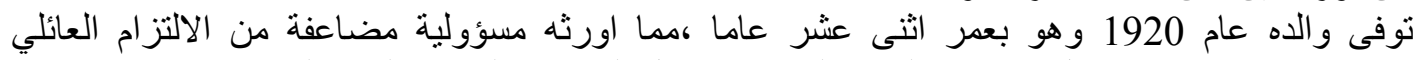

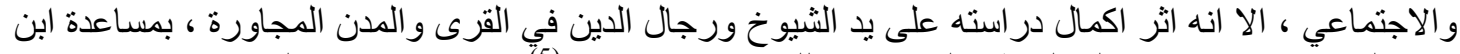

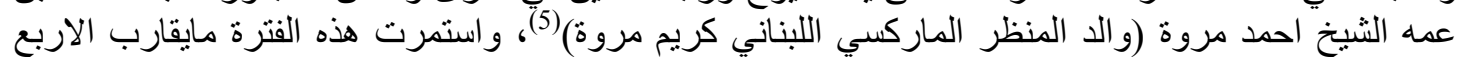

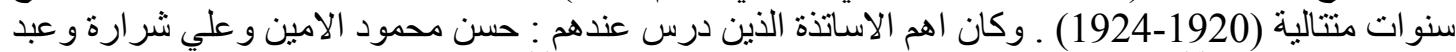

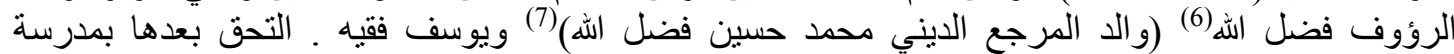

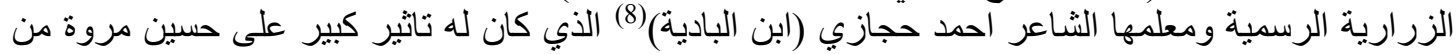

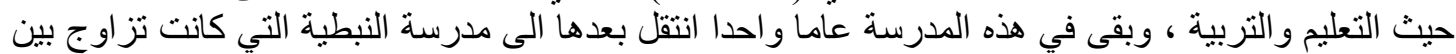

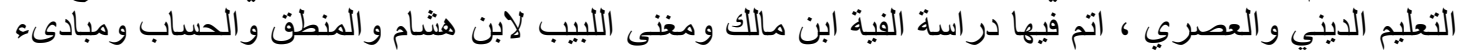

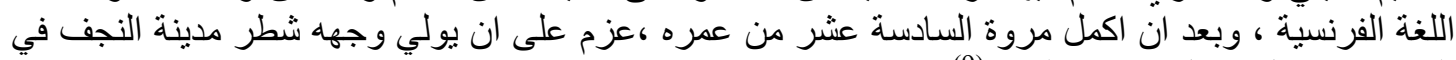

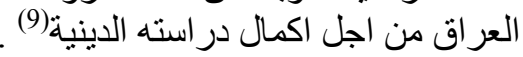

\section{ثانيا : حسين مروة في العراق 1924-1949 عزئ}

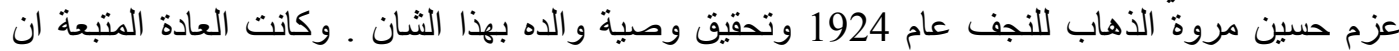

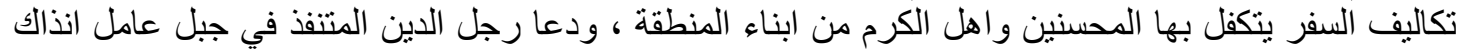

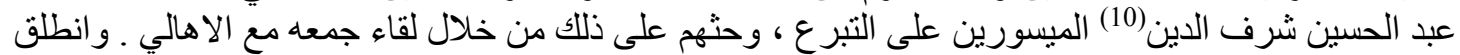

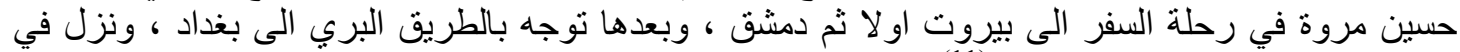

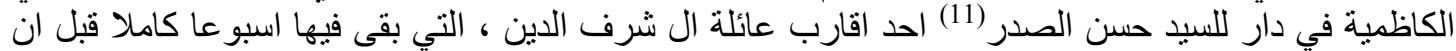

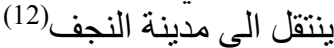

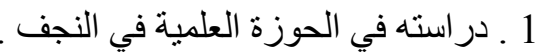

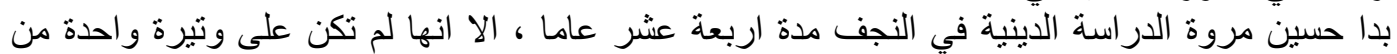

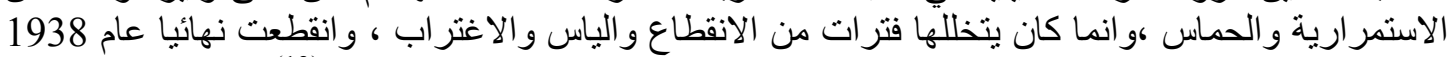

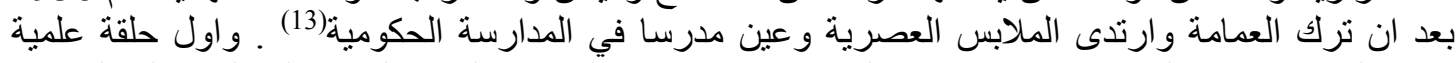

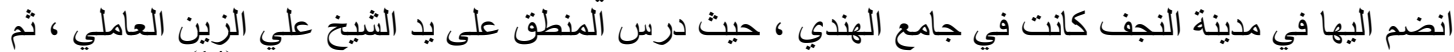

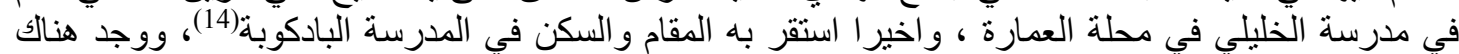

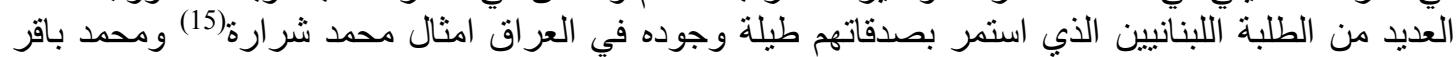

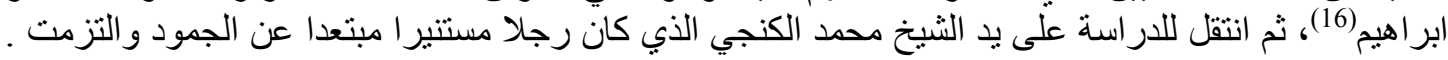

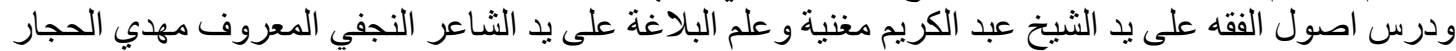

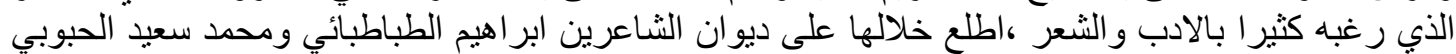

و غير هم (17)

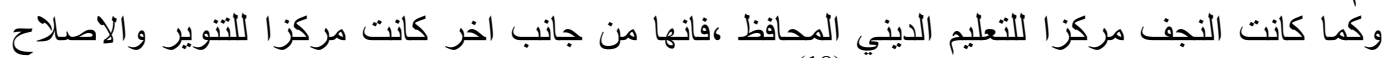

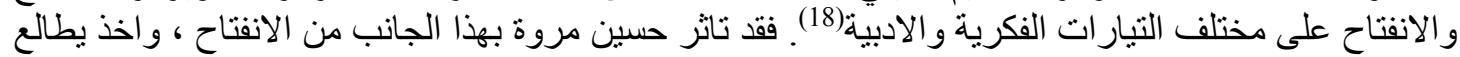

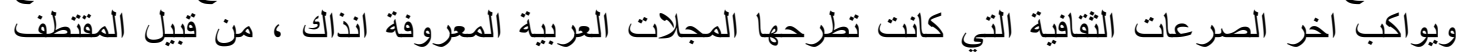

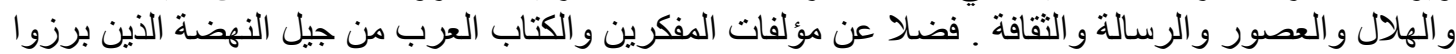

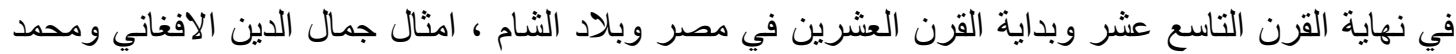

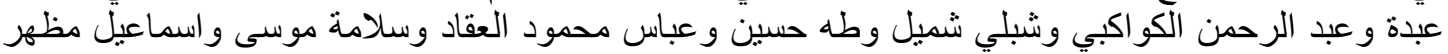

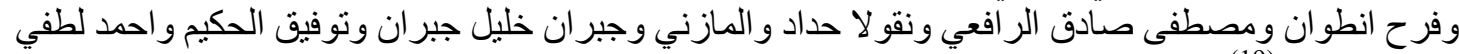

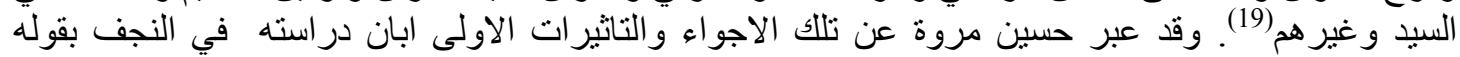

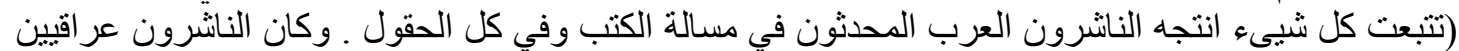

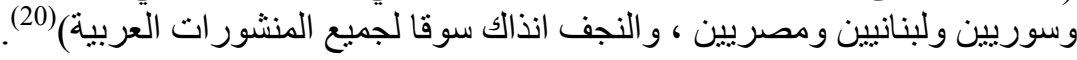




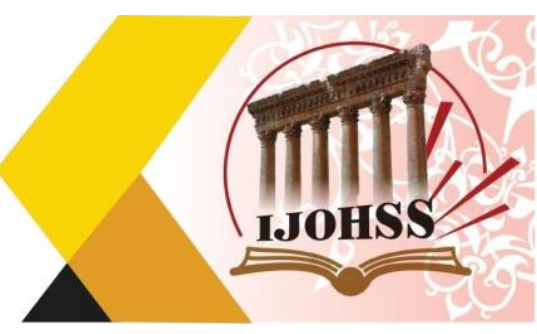

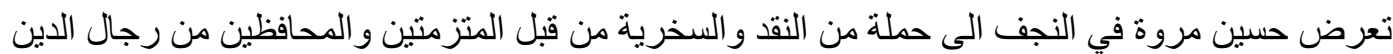

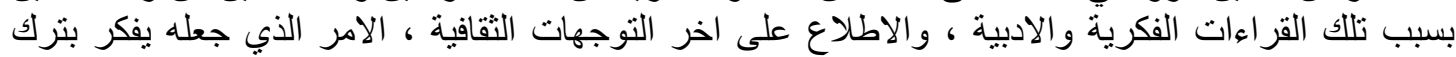

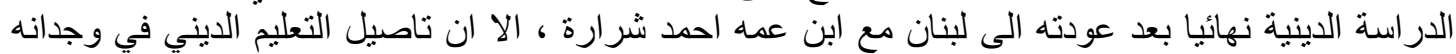

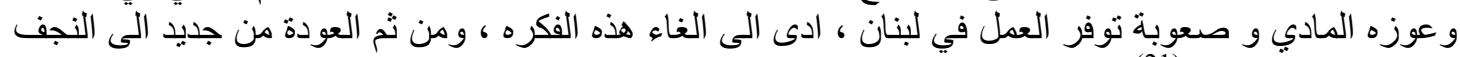

لاكمال در استه الدينية (21).

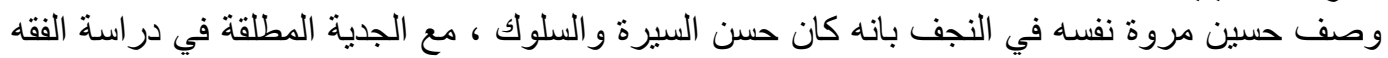

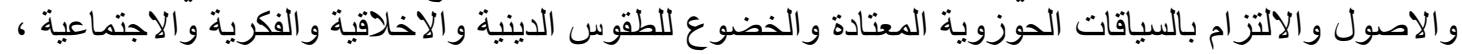

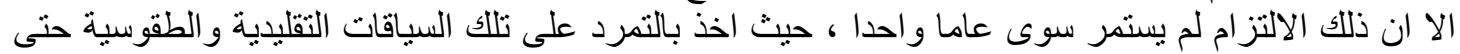

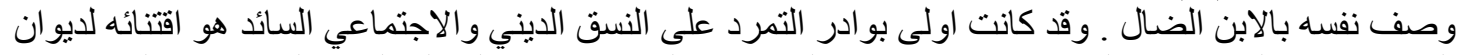

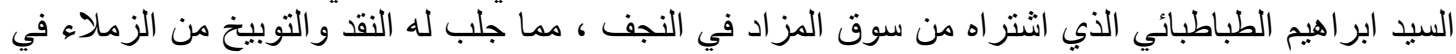

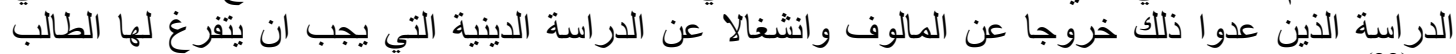

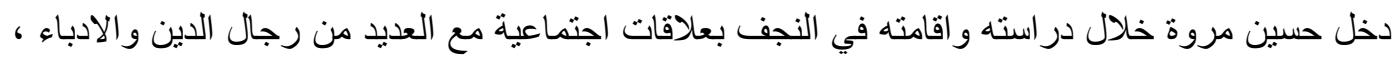

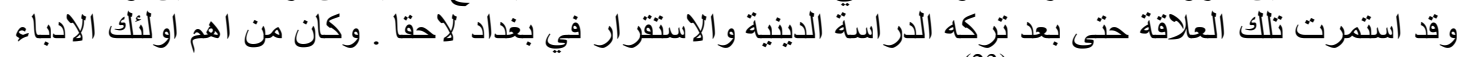

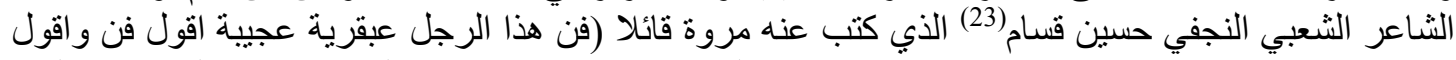

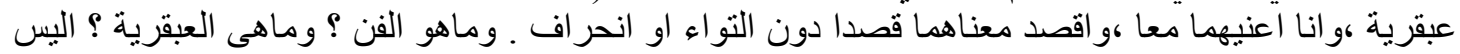

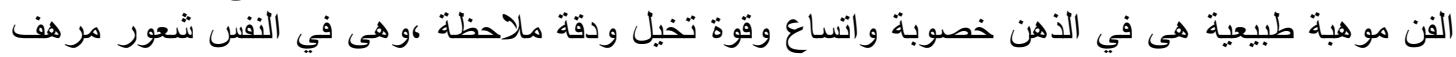

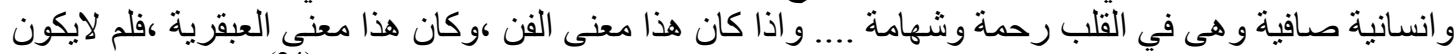

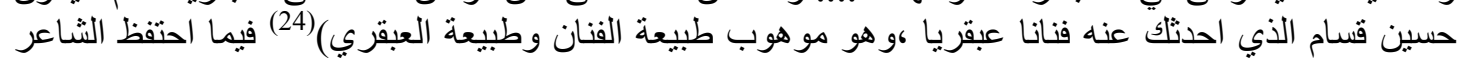

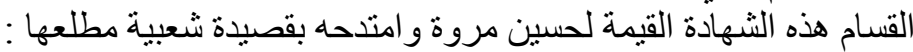

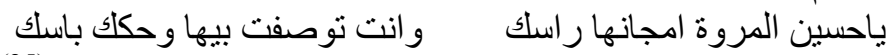

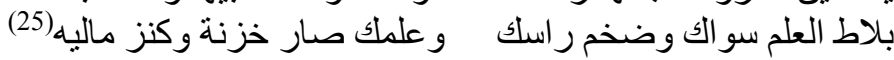

2 اخذت الافكار الاصلاحية والتنويرية تلقي بناثير اتها المباشرة على والثية وجدان حسين مروة و الطلبة المصاحبين

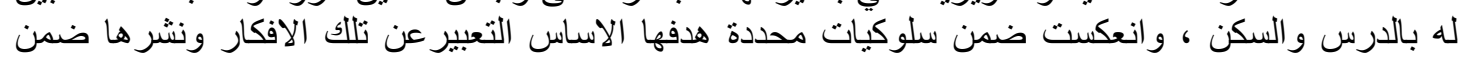

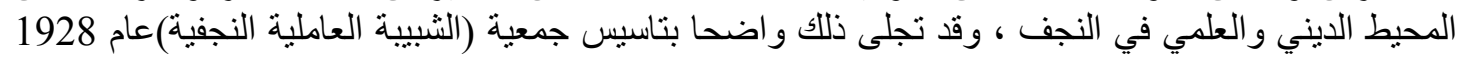

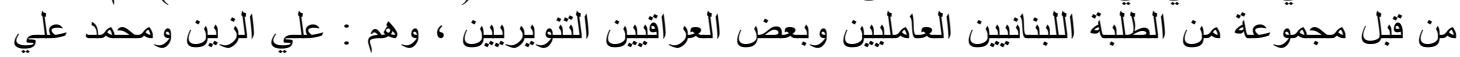

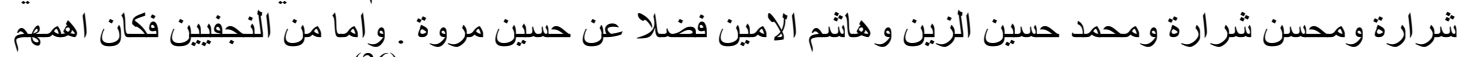

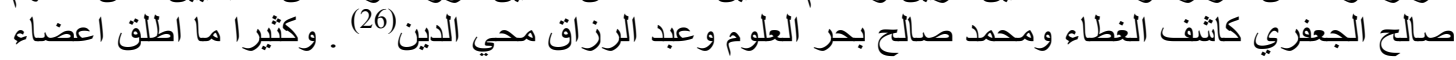

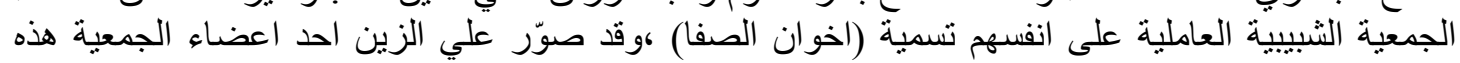

\section{اتخذت نهاها مرشدا ودليلا

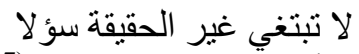

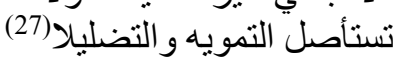

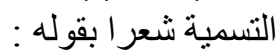

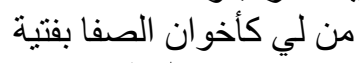

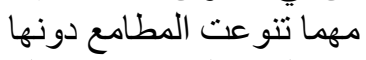

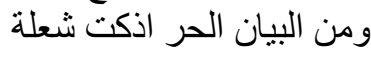

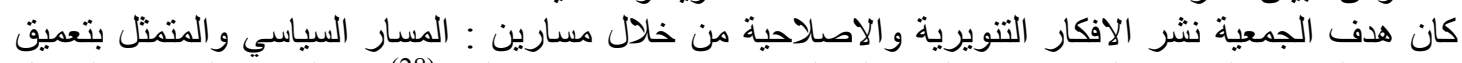

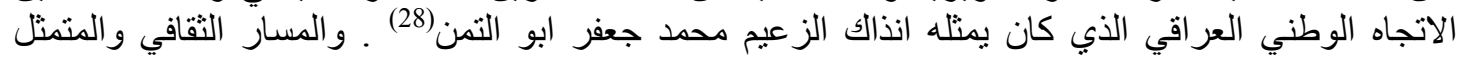

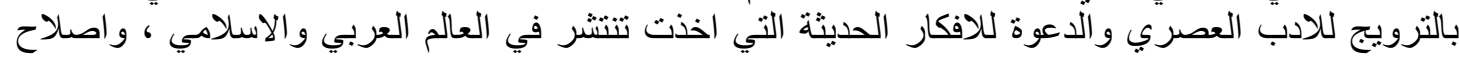

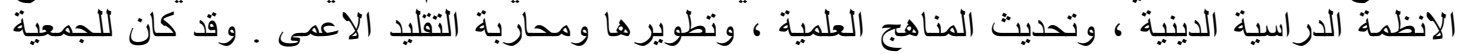

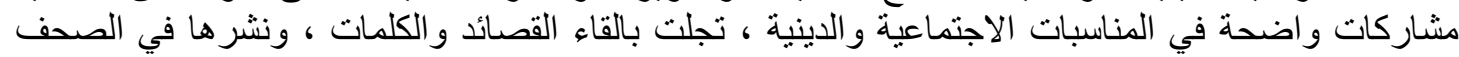

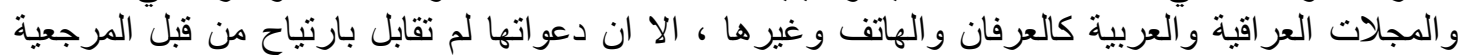
الدينية في النجف (29) - (29)

وقد اثثارت المقالات الثناث التي كتبها احد اعضاء الجمعية وهو محسن شرارة(30) في مجلة العرفان اللبنانية

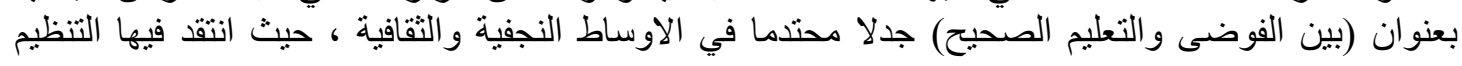




\section{المجلة اللدولية اللملوم الآنسانية والإمتماعية}

International Journal of Humanities and Social Sciences

website:www.ijohss.com

Email:editor@ijohss.com

ISSN: $2415-4822$
مارس 2021

Volume (19)
(19) (لعدا

March 2021

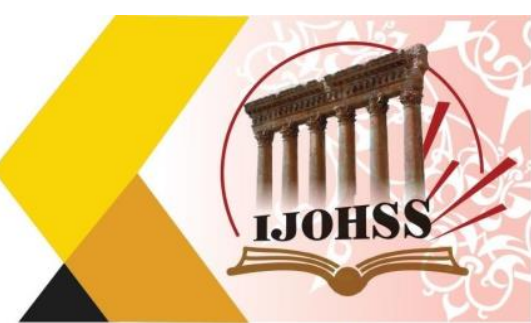

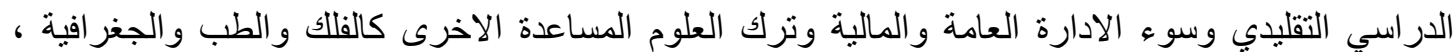

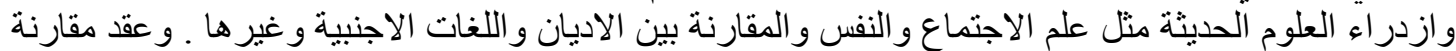

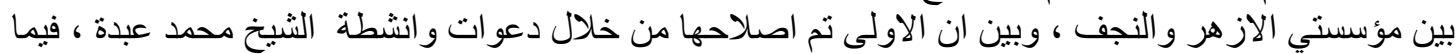

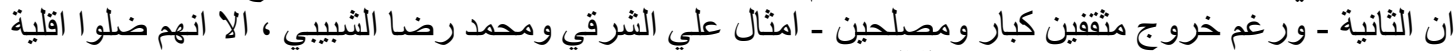

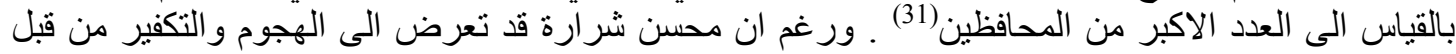

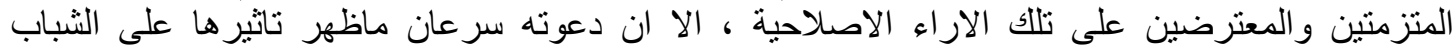

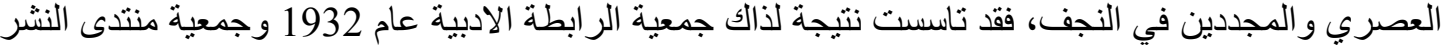

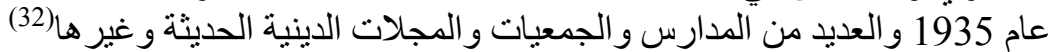

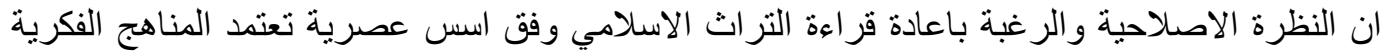

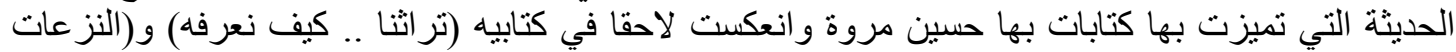

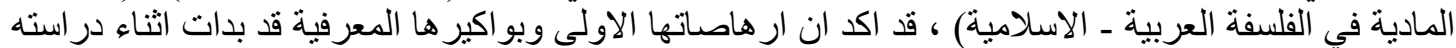

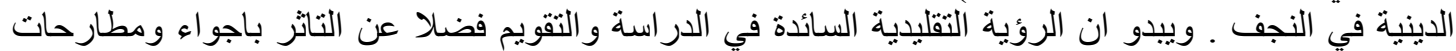

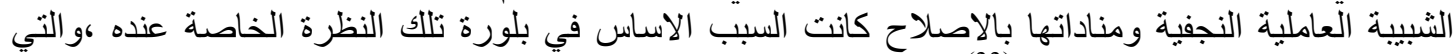

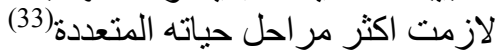

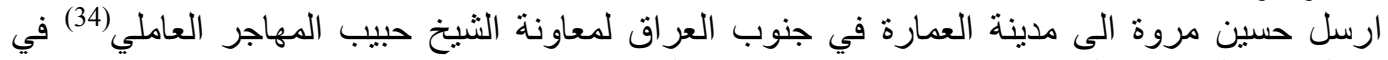

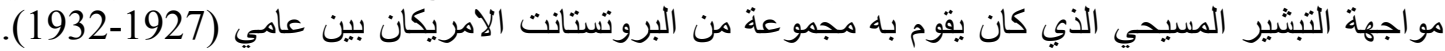

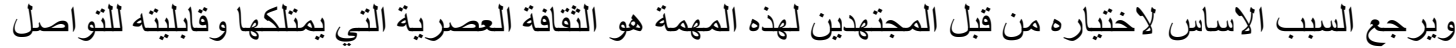

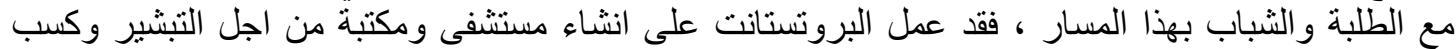

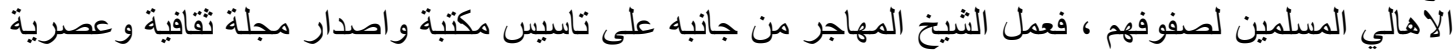

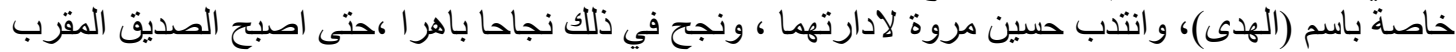

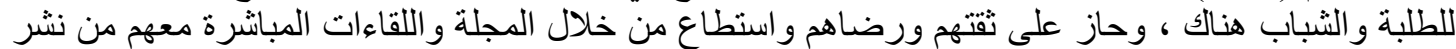

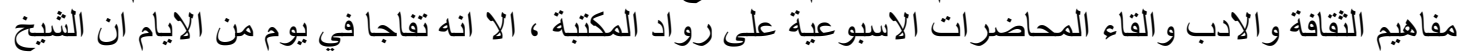

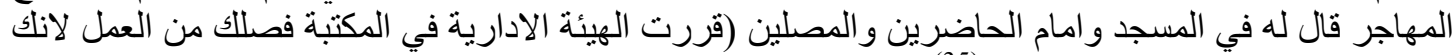

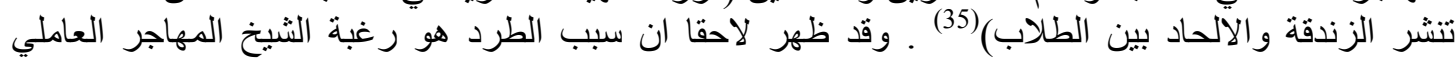

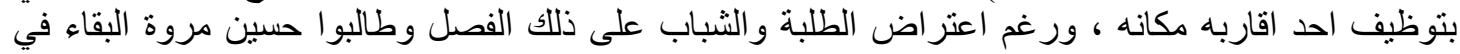

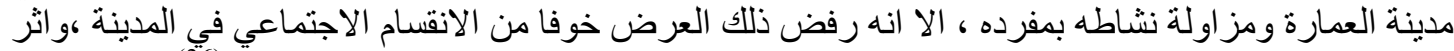

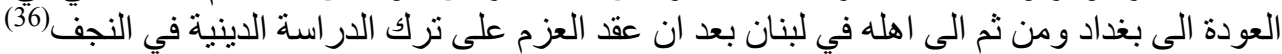

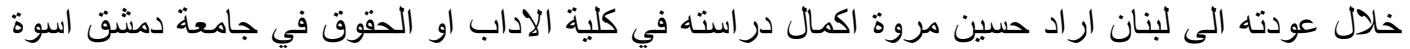

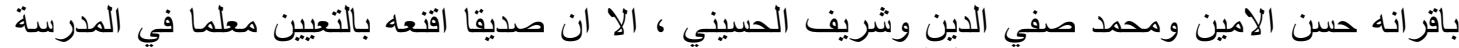

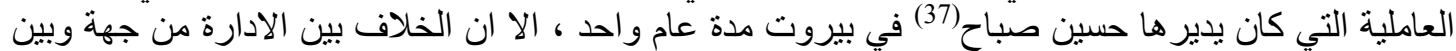

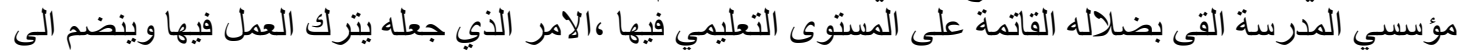

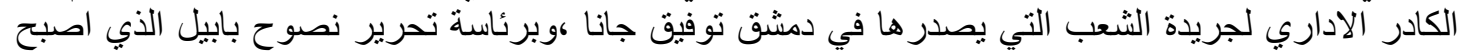

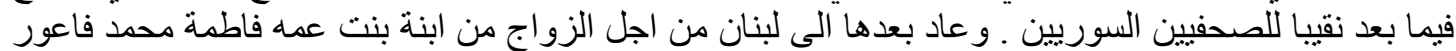

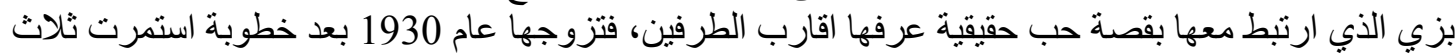

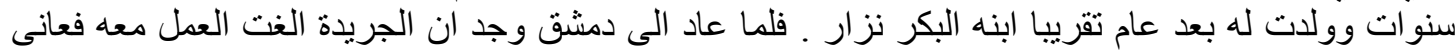

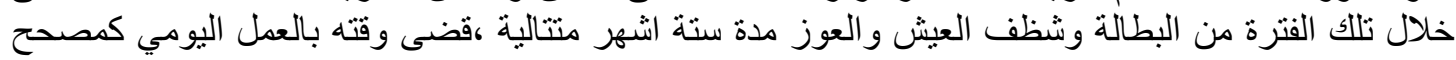

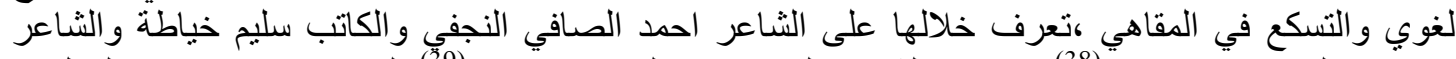

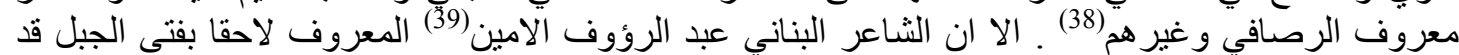

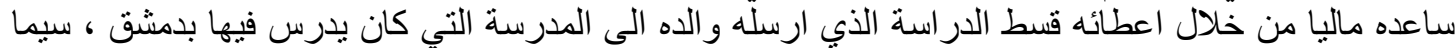

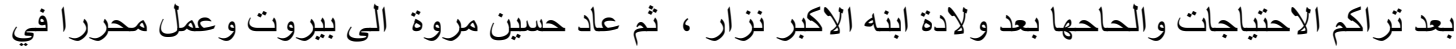

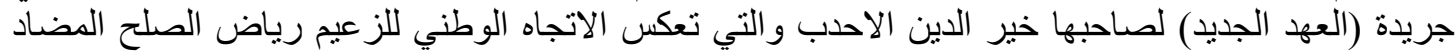

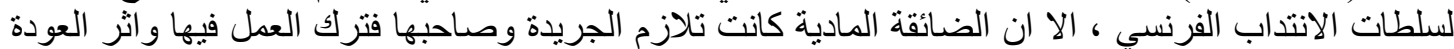

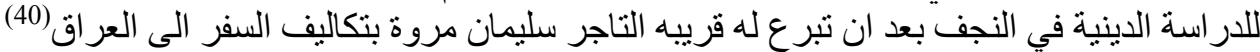




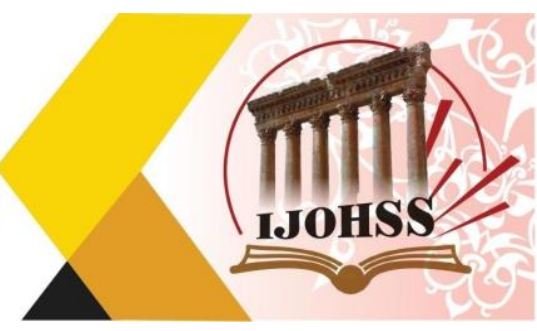

عاد حسين مروة للار اسة الدينية في النجف عام 1934 وحصل في العام التام التالي (1935) على الجنسية

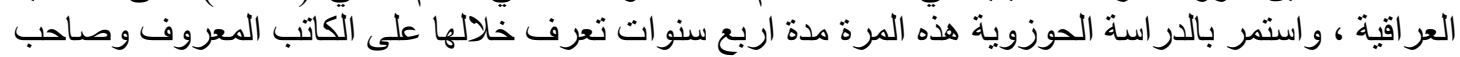

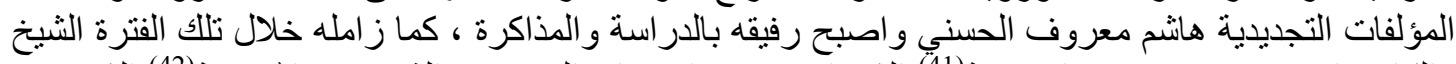

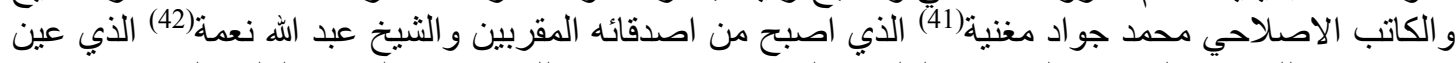

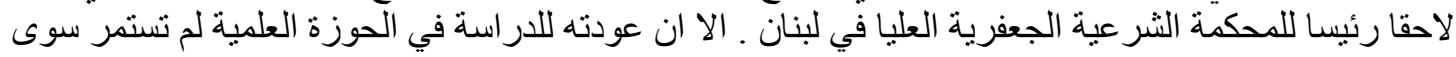

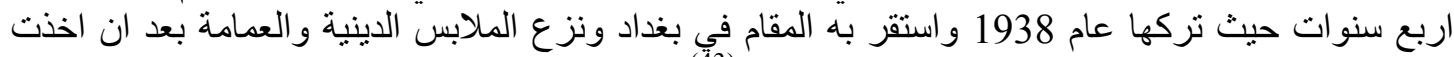

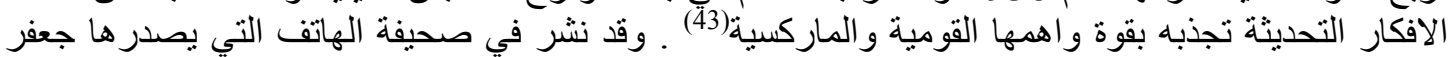

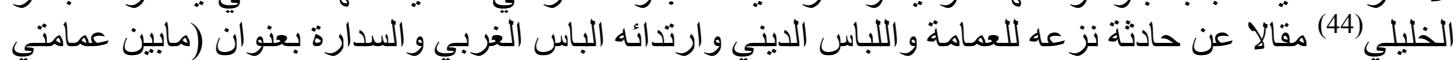

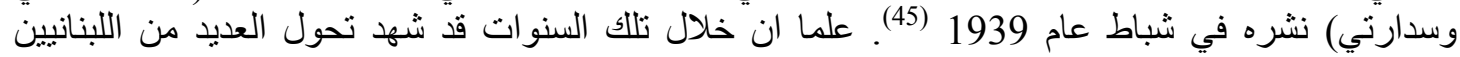

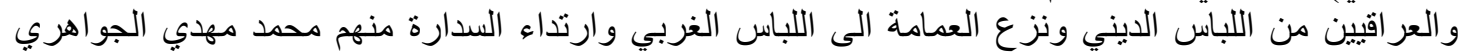

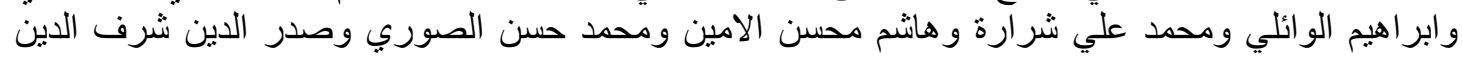

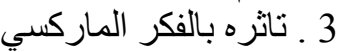

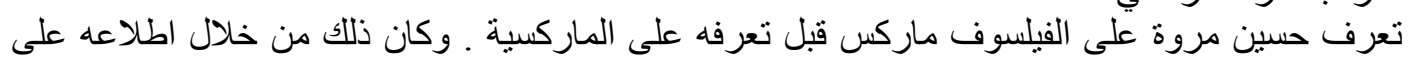

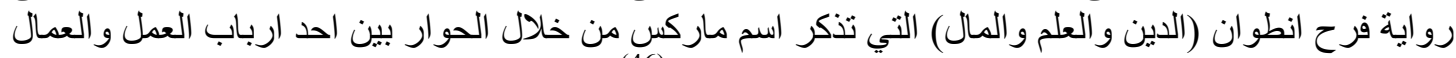

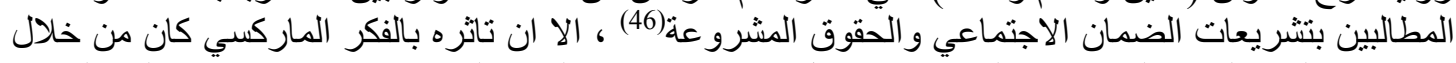

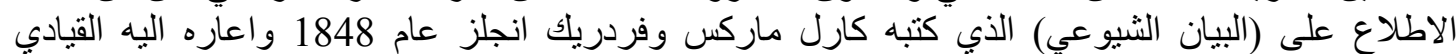

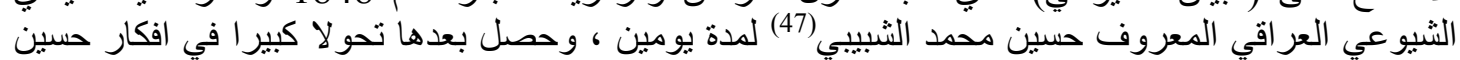

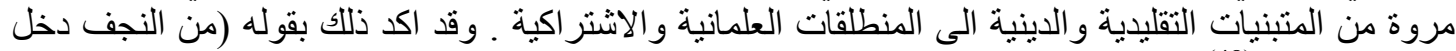

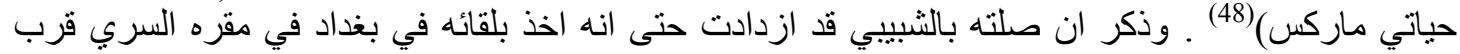

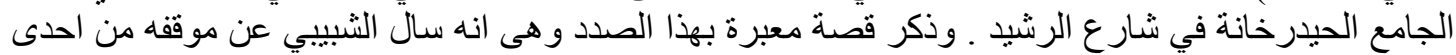

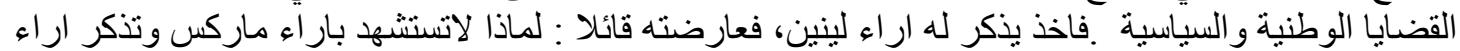

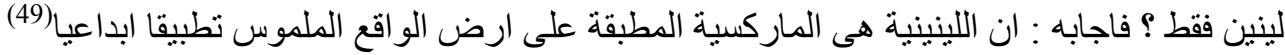

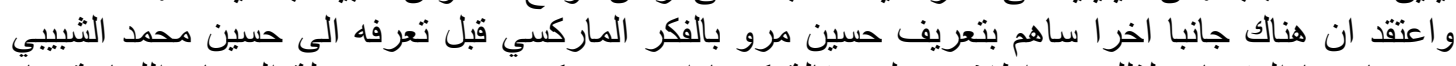

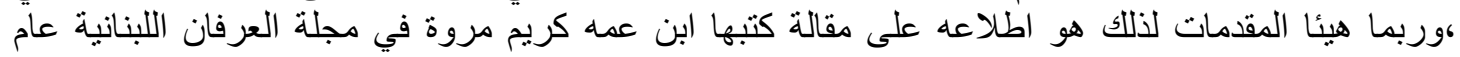

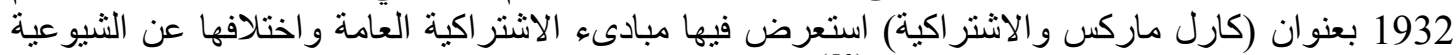
وموانع انتشار ها في العالم العربي والإن الاسلامي (50).

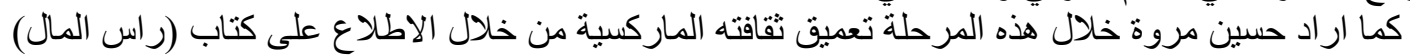

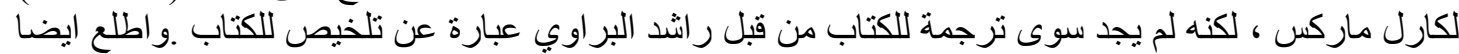

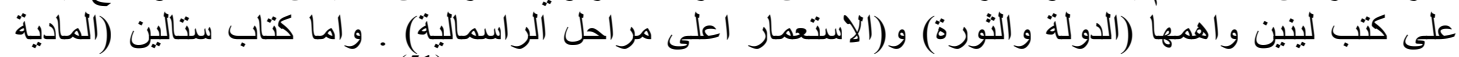

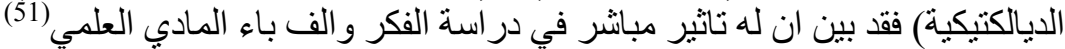

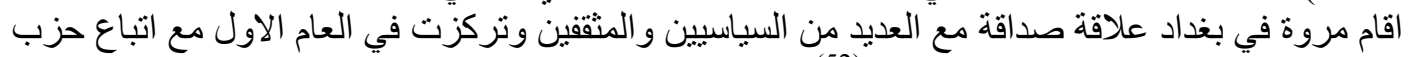

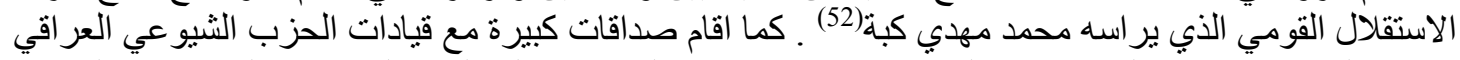

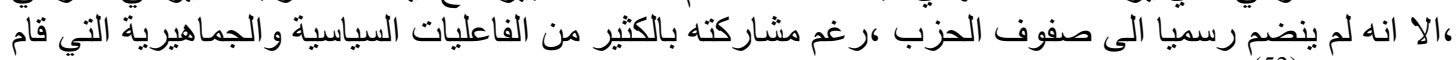
بها في بغداد(53). 4

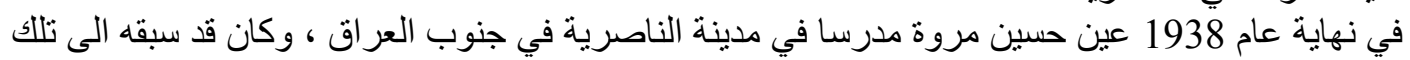

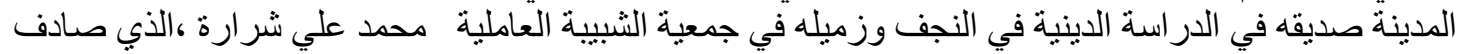

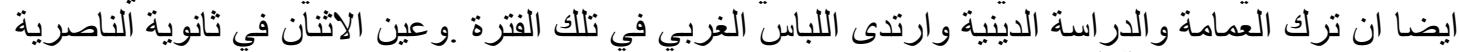

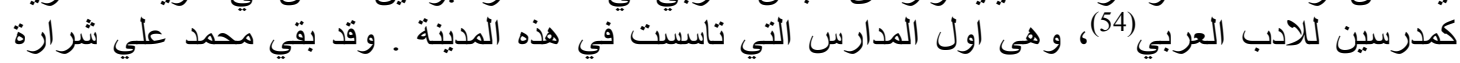

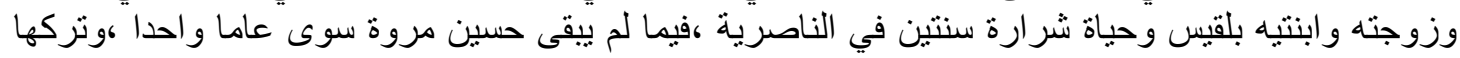

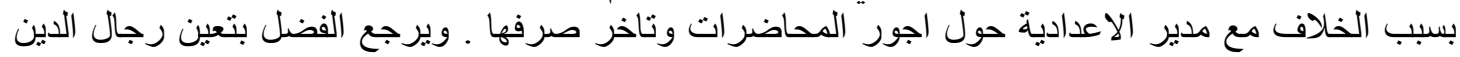




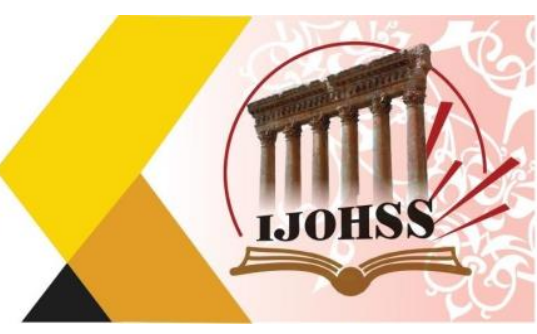

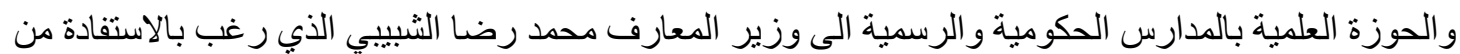

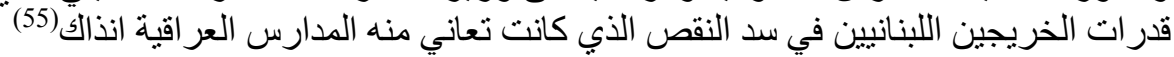

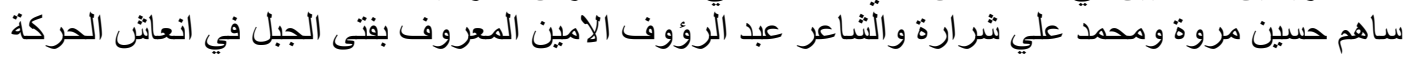

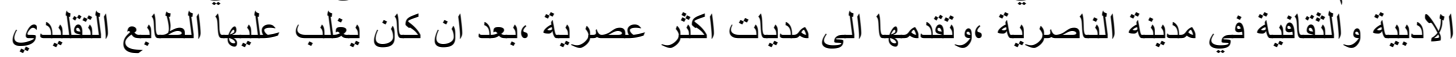

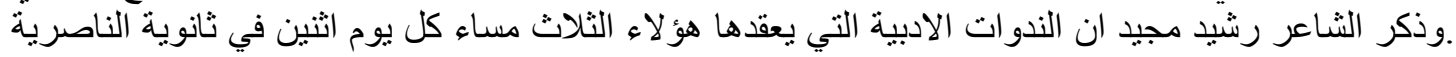

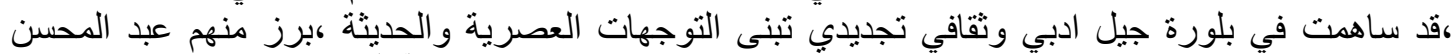

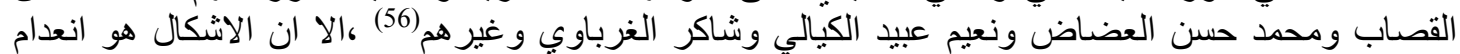

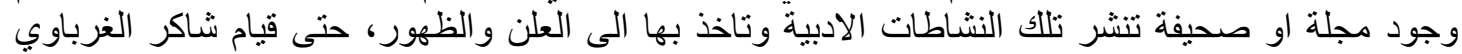

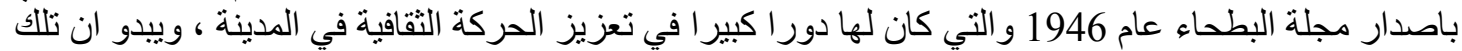

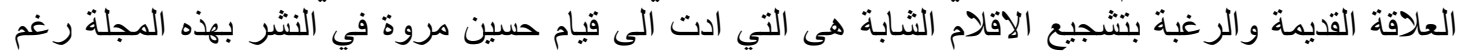
تركه لها عام 1939 ـ فقد نشر قطعة نثرية في العدد الحادي عشر تقترب من القيام القصة بعنوان (خدعة النقان الثيطان) (57).

$$
5
$$

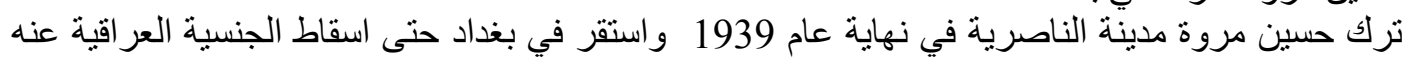

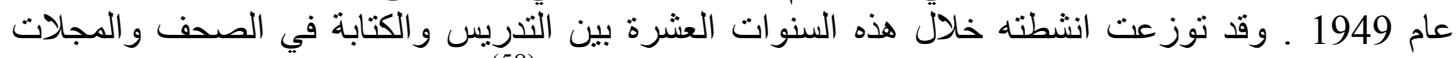

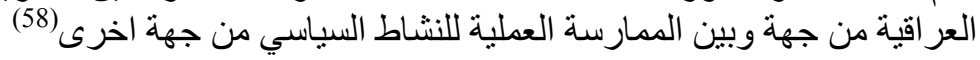

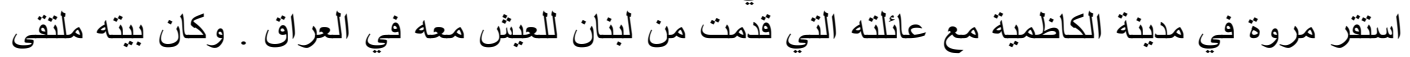

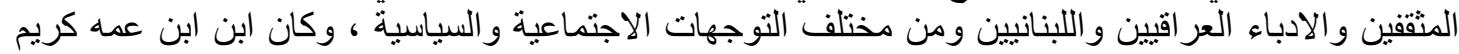

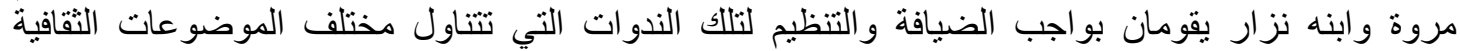

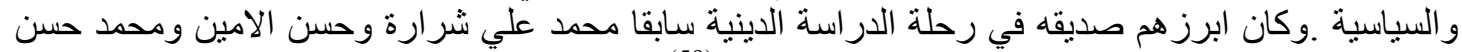

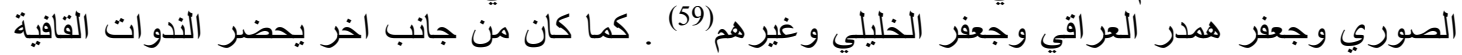

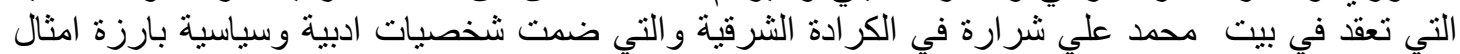

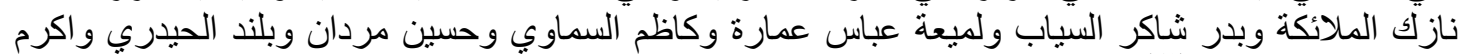

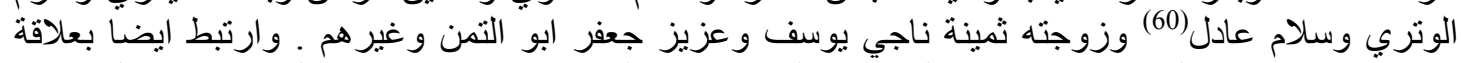

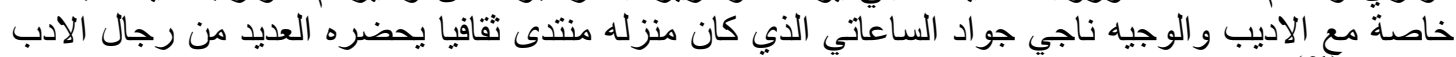
و السياسة(61)

عمل حسين مروة خلال تلك الفترة مدرسا للادب العربي في المدرسة الجعفرية ومدرسة شماس اليهودية

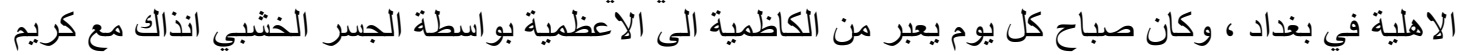

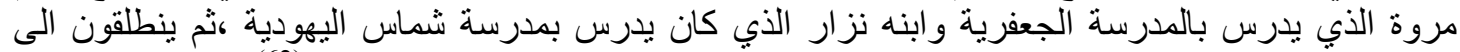

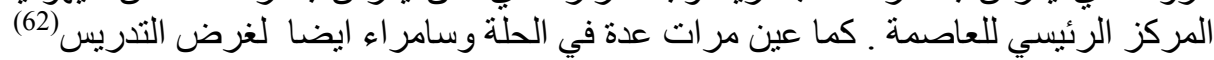

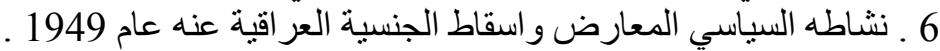

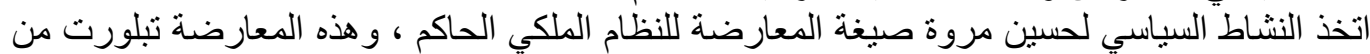

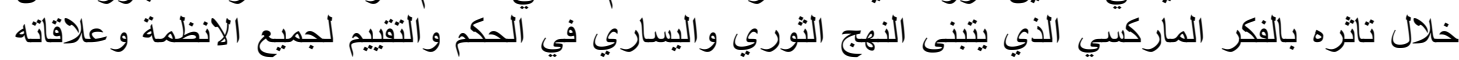

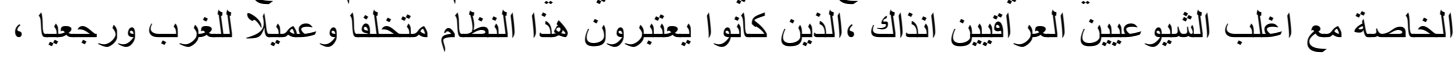

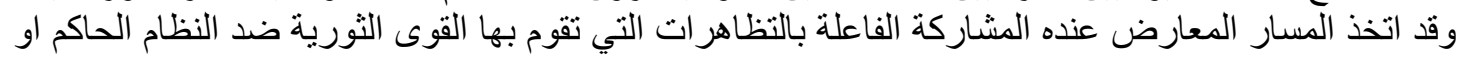

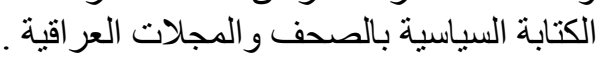

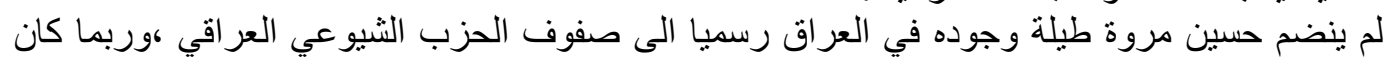

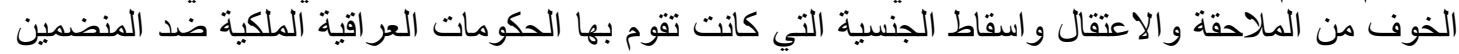

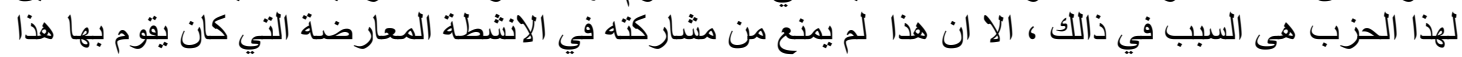

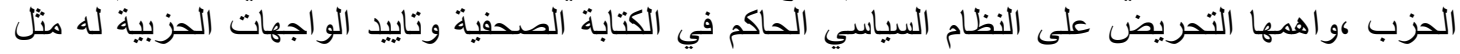

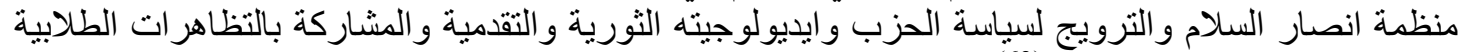
التي ينظمها ضد السلطة الحاكمة:(63). 


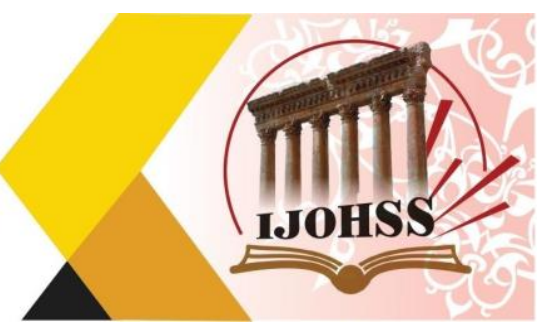

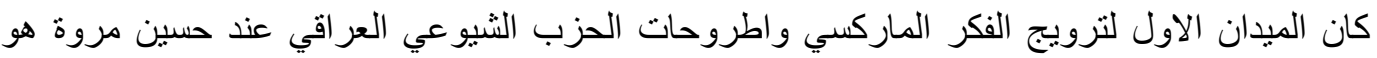

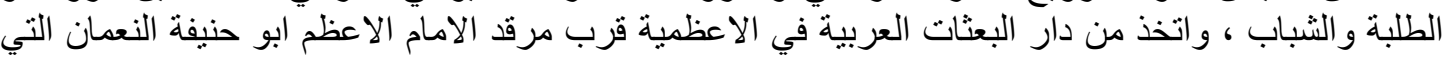

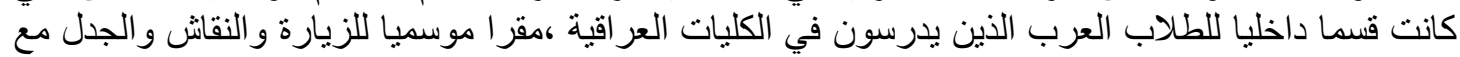

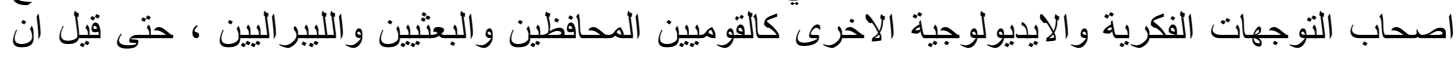

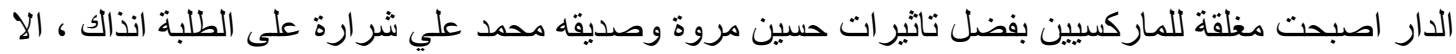
ان قدوم الثاعر البعثي السوري سليمان العيسى وفائز اسماعيل في منتصف الإنين الاربعينات قد ساهم بنشر الافكار

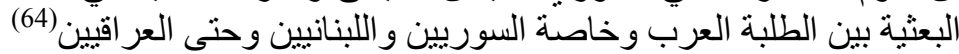

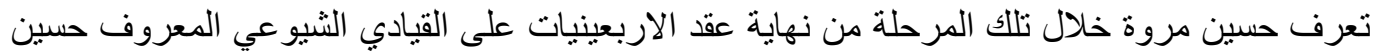

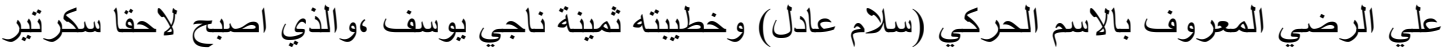

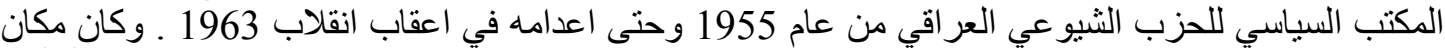

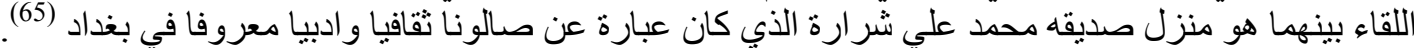

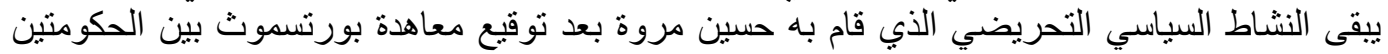

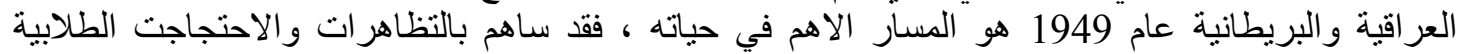

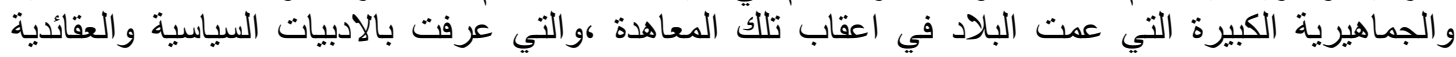

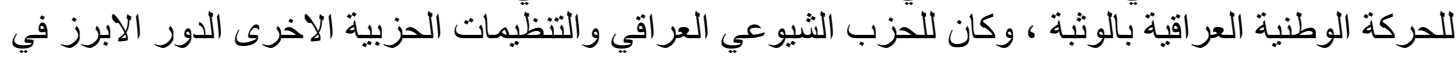

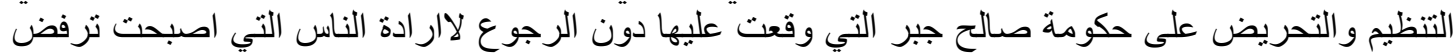

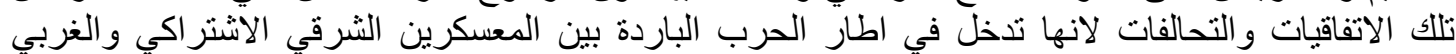

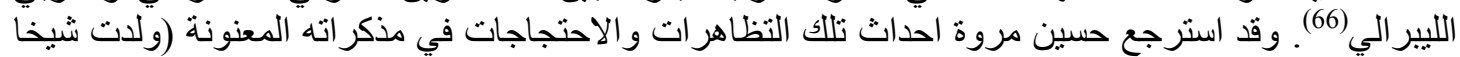

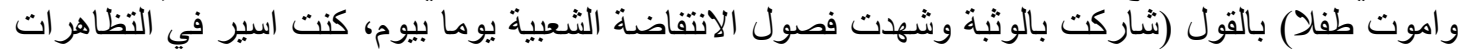

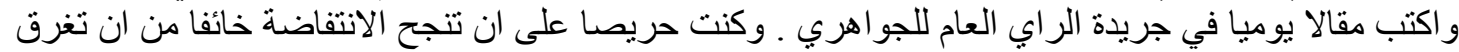

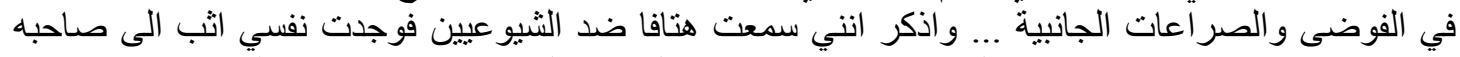

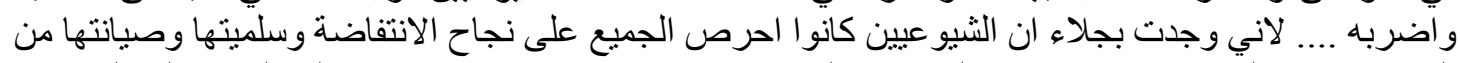

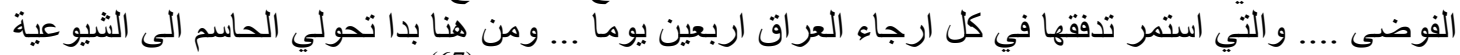

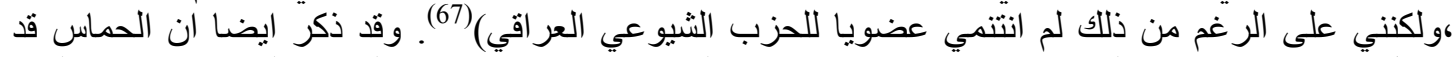

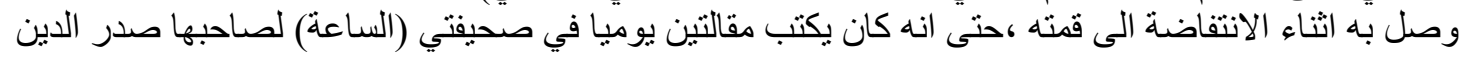

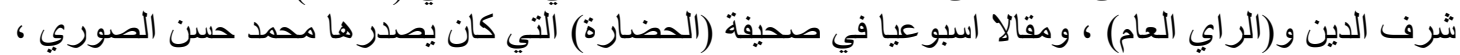

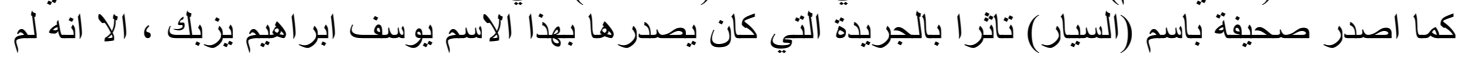

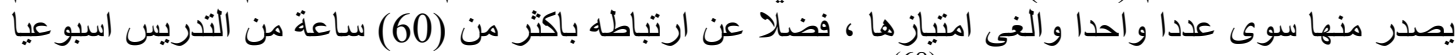

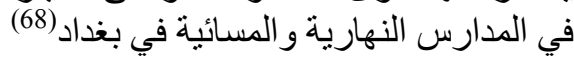

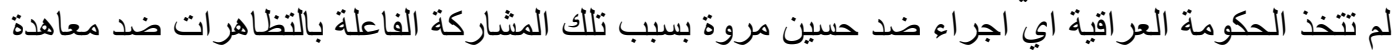

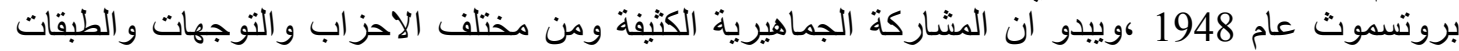

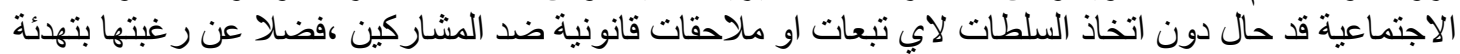

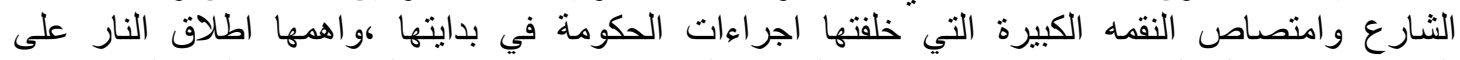

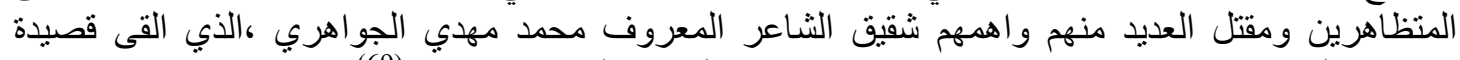

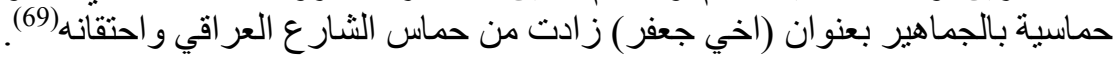

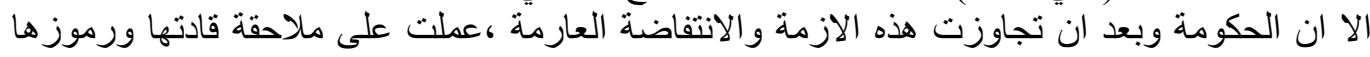

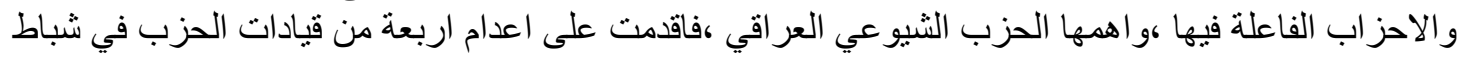

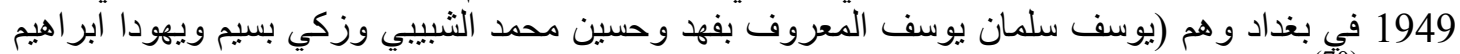

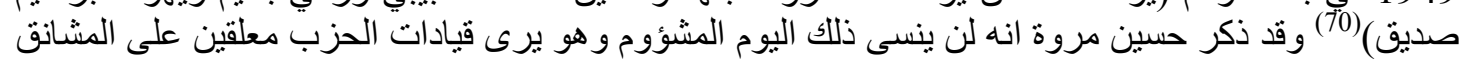

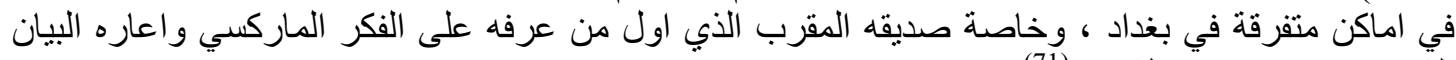
الثيو عي حسين محمد الثبيبي (71). وأما حسين مروة فقد اسقطت الحكومة العراقية الجنسية عنه بعد ان نشر في جريدة الحضارة مقالا بعنوان (العقل و العاطفة عند نوري السعيد) ردا على مقالة سبق ان كتبها رئيس الوزر اء السابق نوري السئ السعيد دعا فيها 


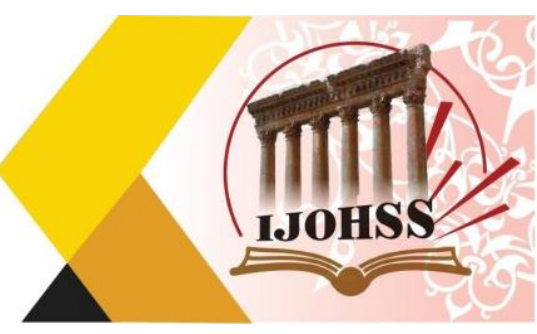

الثعب العر اقي للركون للعقل بدل العاطفة ـ وجرى اسقاط الجنسية العر اقية عنه و ابعاده مع عائلته الى لبنان في

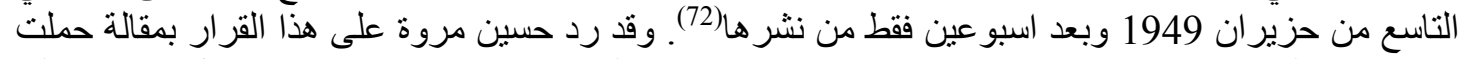

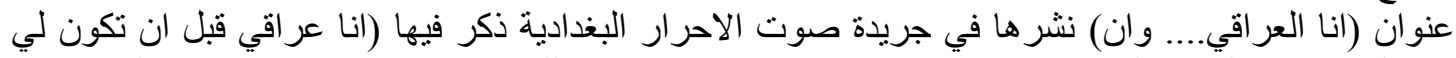

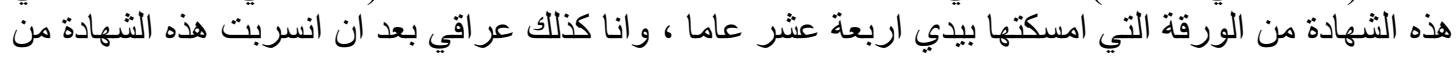

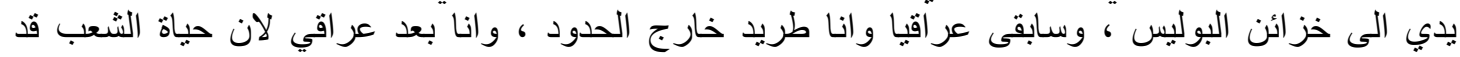

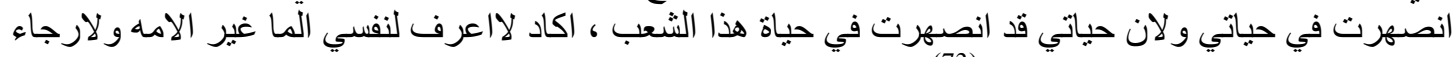

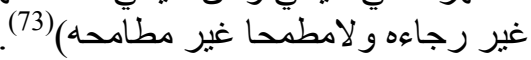

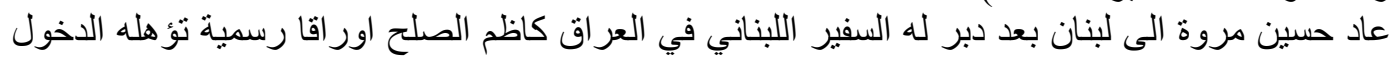

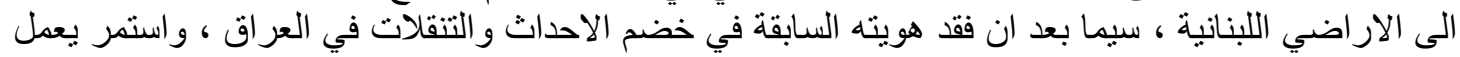

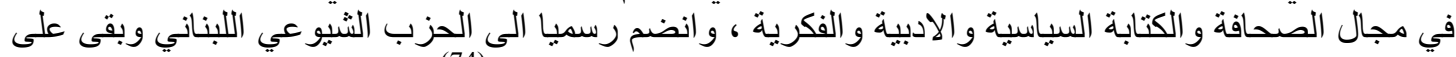

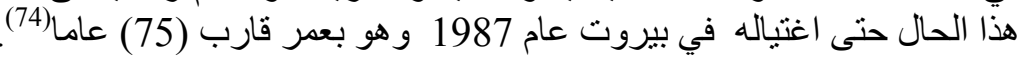

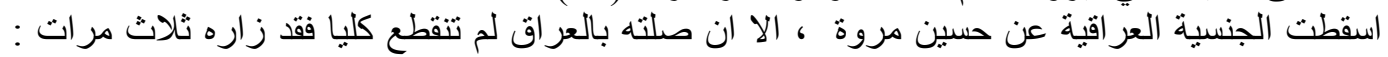

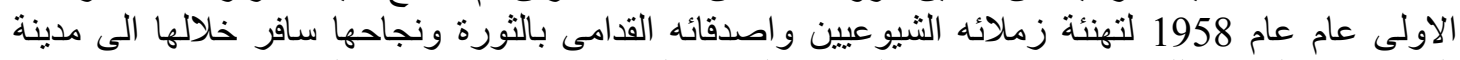

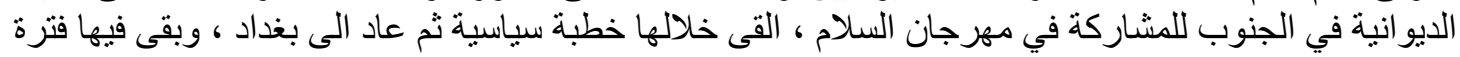

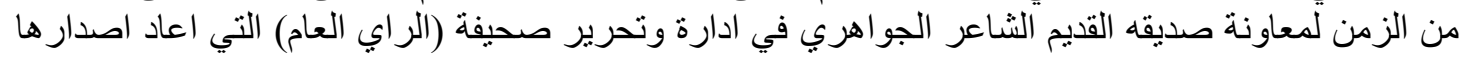

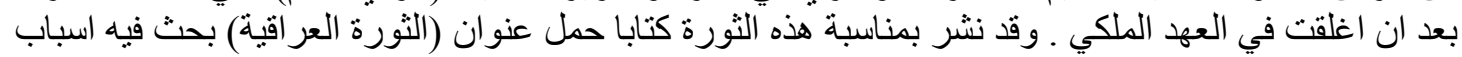

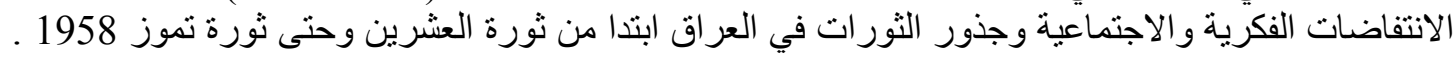

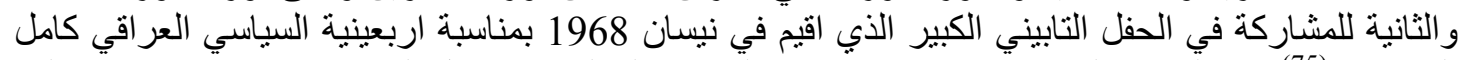

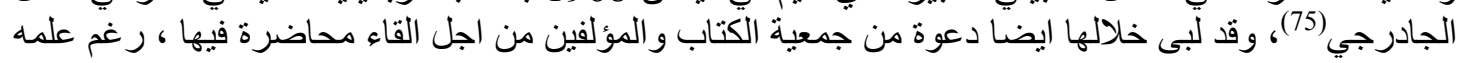

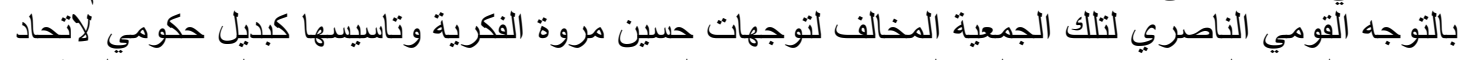

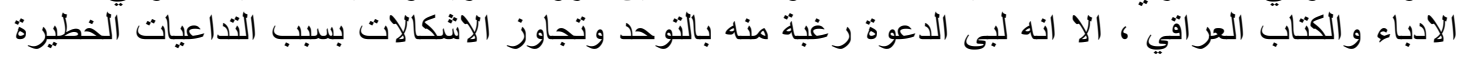

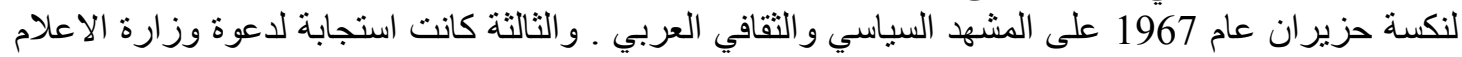

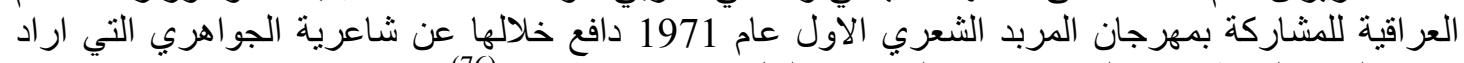

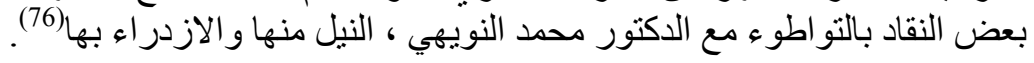

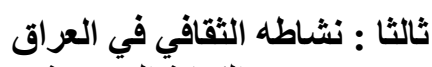

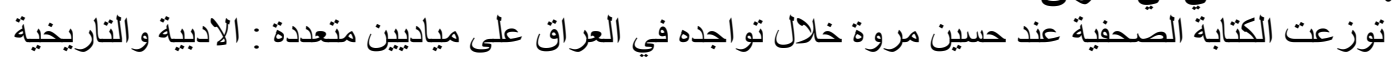

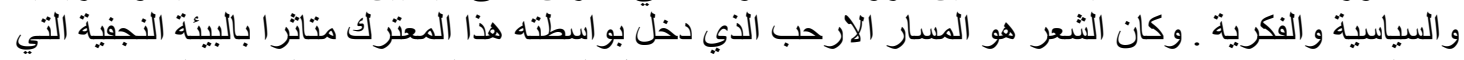

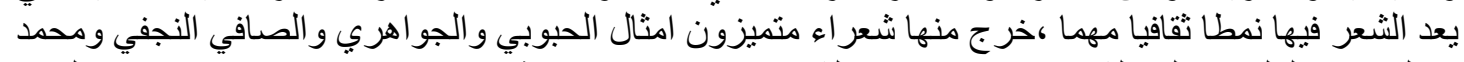

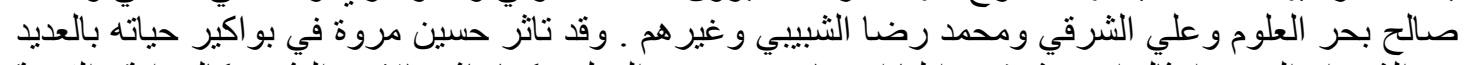

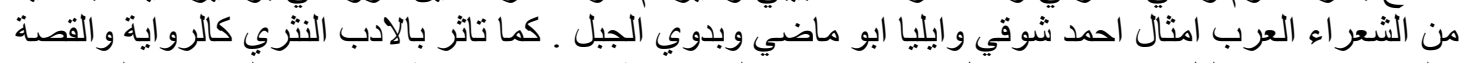

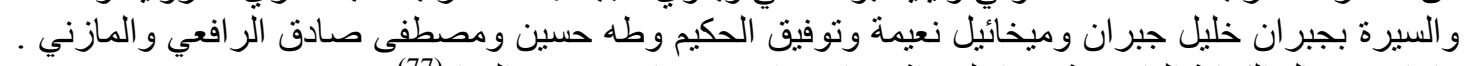

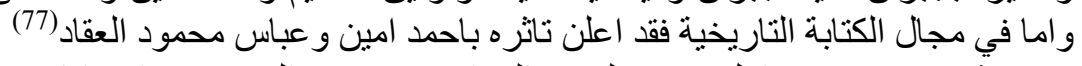

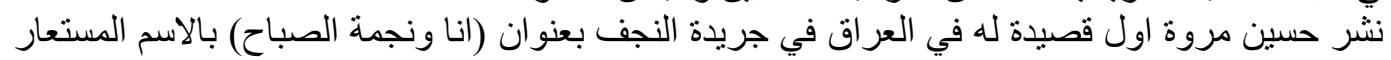

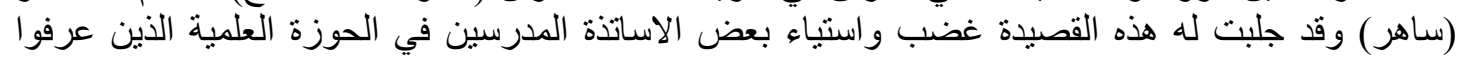

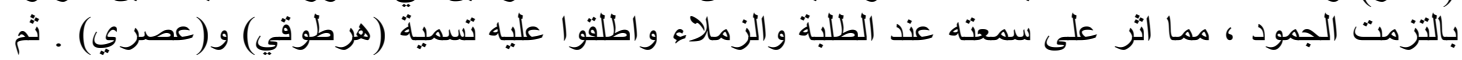

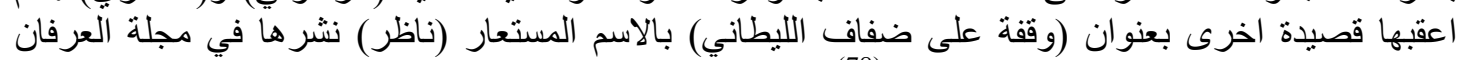

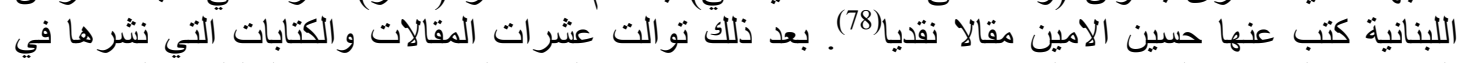

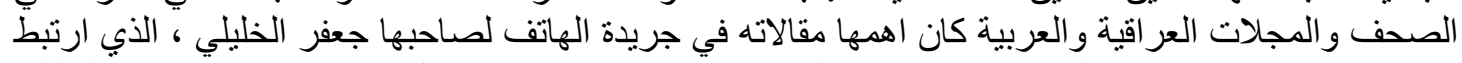

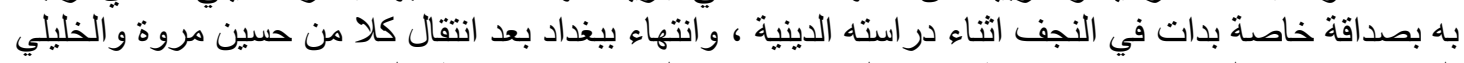

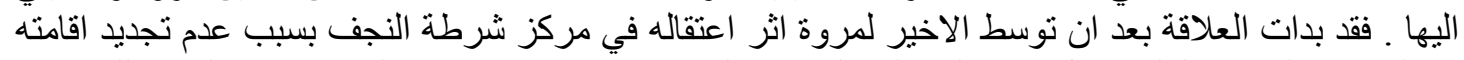

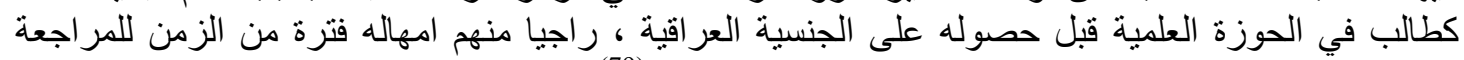

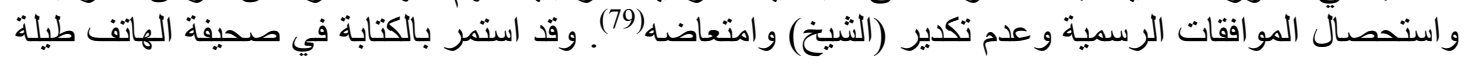




\section{المجلة اللدولية اللملوم الآنسانية والإمتماعية}

International Journal of Humanities and Social Sciences

website:www.ijohss.com

Email:editor@ijohss.com

ISSN: $2415-4822$
مارس 2021

Volume (19)
(19) (لعدا

March 2021

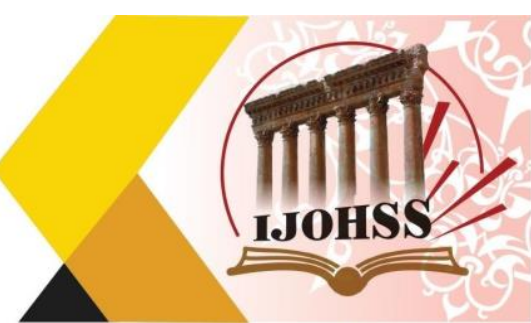

ستة سنو ات متتالية بين عامي 1934-1940 واعتبر ها حسين مروة مصدرا مهما لار اسة المطارحات الفكرية

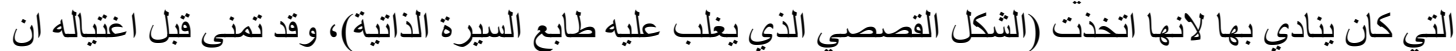

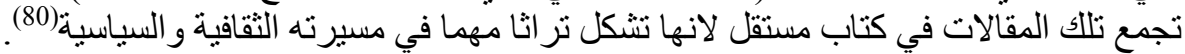

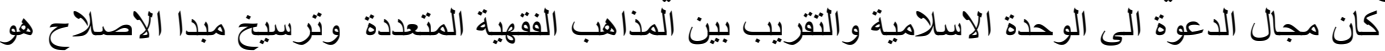

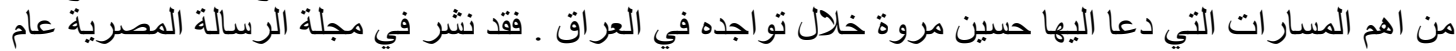

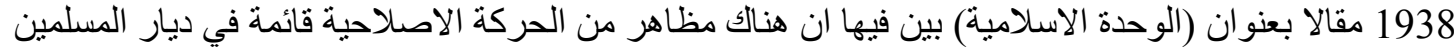

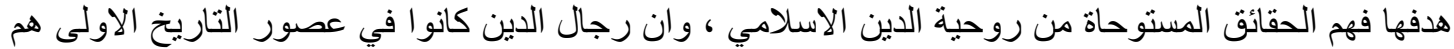

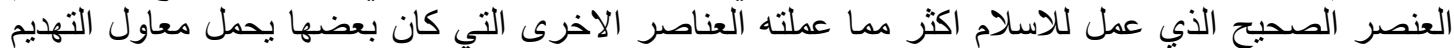

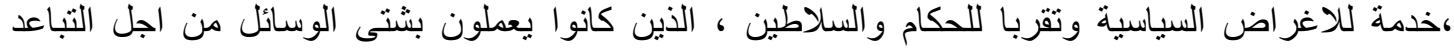

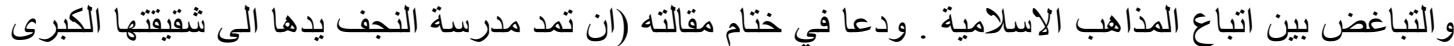

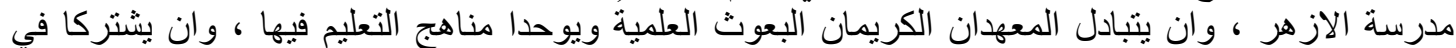

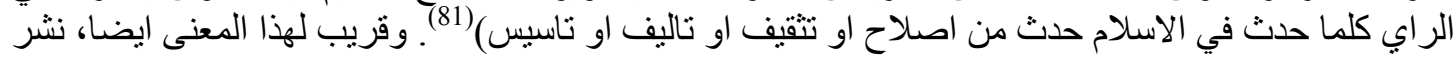

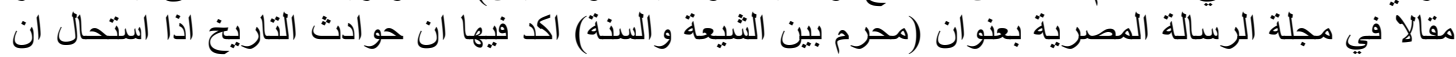

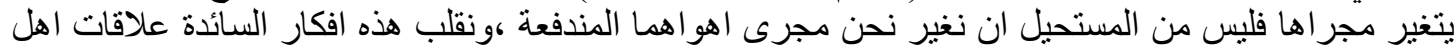

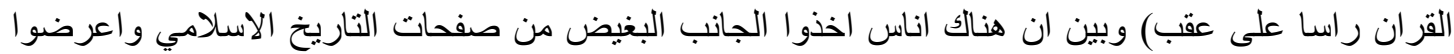

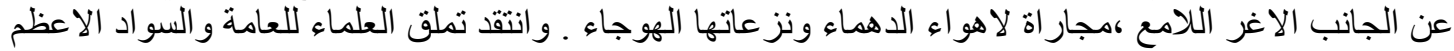

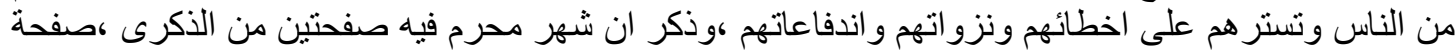

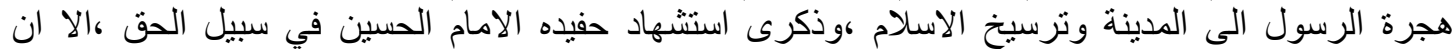

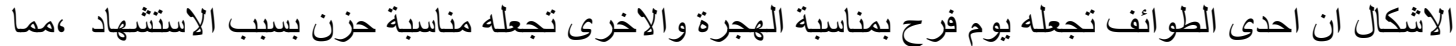

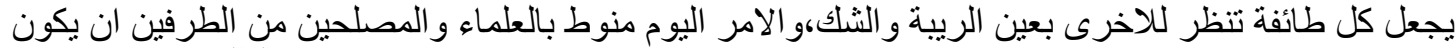

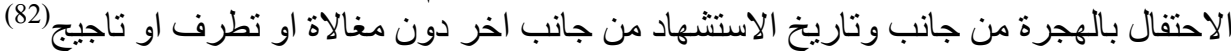

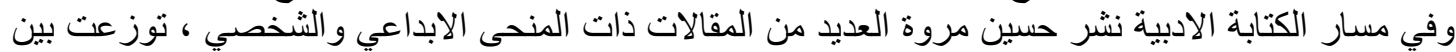

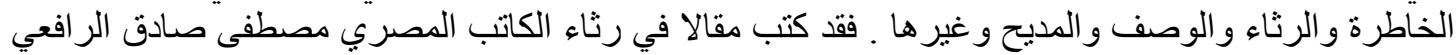

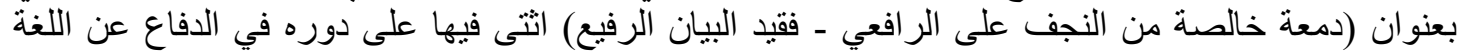

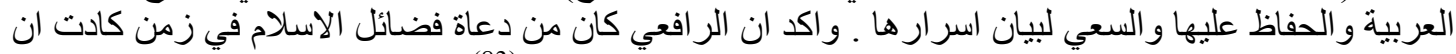

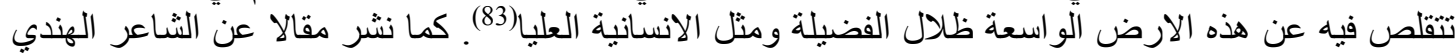

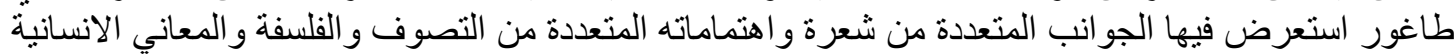

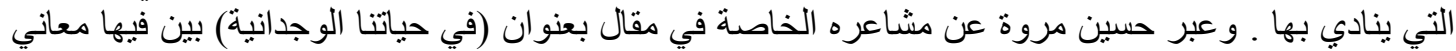

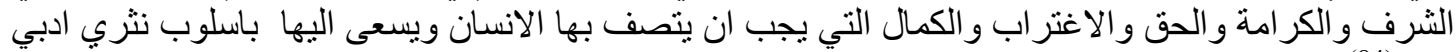

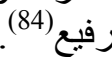
و واما في مجال الكتابة السياسية فقد كانت الاحداث السائدة في عصره كالقضية الفلسطينية و الموقف من الاستعمار

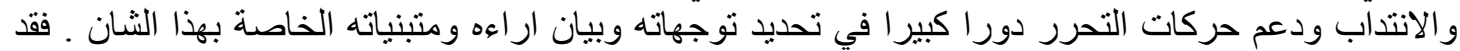

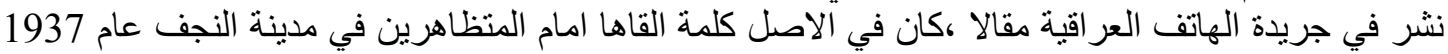

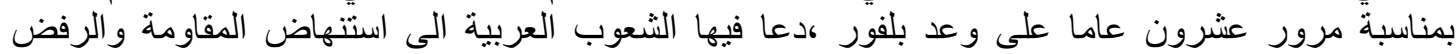

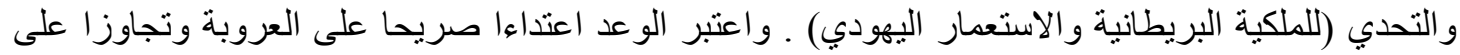

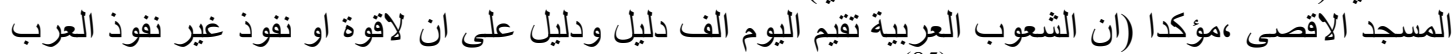

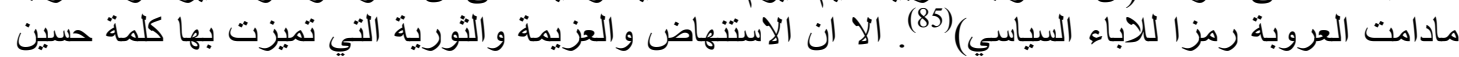

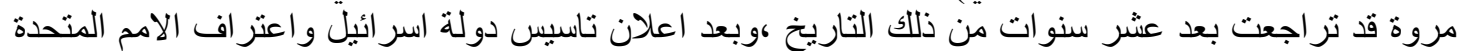

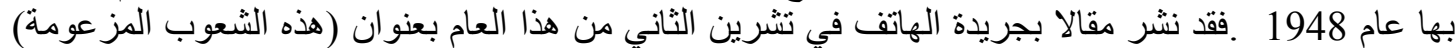

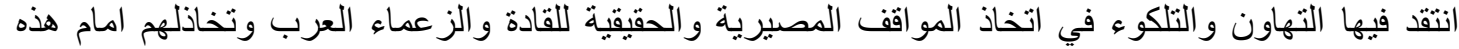

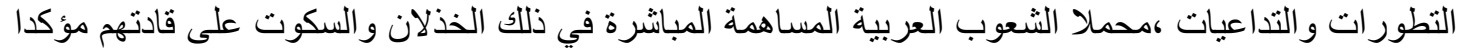

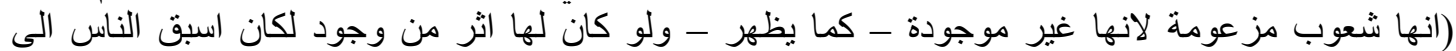
الاعتر اف بهاز عماؤها الذين يسوسون امر ها ويصر هوفون شؤونها ويحملون اقدار ها) (86). 


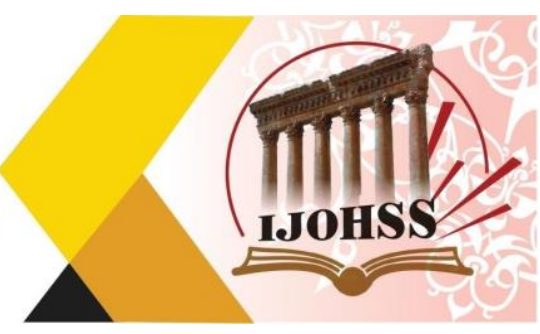

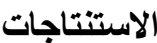

1 ـ ان تاثثر حسين مروة بالثقافة العر اقية والتفاعل مع الاحداث السياسية خلال تللك المرحلة من حياته كان ظاهر ا بافر اط في كتاباته ومو اقفه. 2 ـ كانت نشاطاته السياسية المعارضة قدانه تبلورت بقانية بقوة بعد تركه الدراسة الدينية في النجف ، فيما كان يغلب

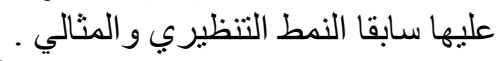
3 ـ ان عدم تكيف حسين مروة مع البيئة المحافظة في مدينة النجف يعد من اهم الاسباب الرئيسية في تركه

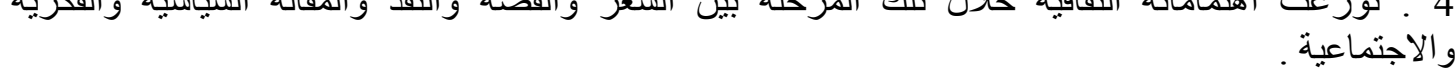
5 ـ كانت التاثير ات الماركسية خلال المرحلة العر اقية قد اسست المفاهيم اللاحقة في مؤلفاته بعد عودته الى لبنان

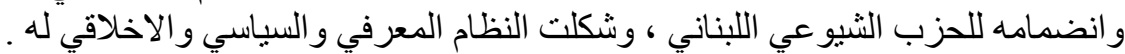

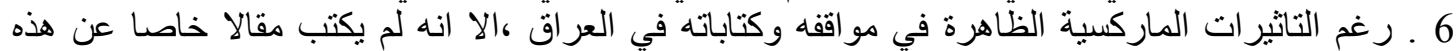

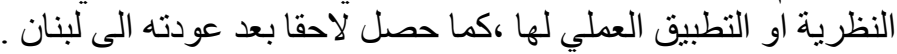

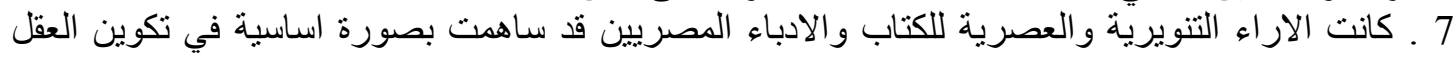

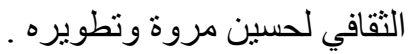

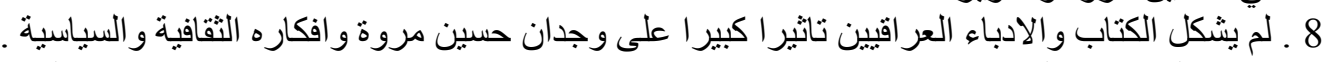

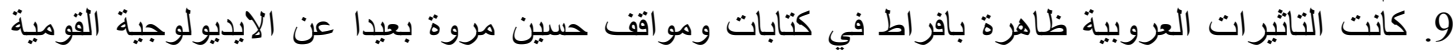

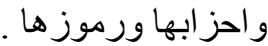
10 ـ شكلت القضية الفلسطينية ركيزة اساسية في كتاباته ومو اقفه السياسية في العراق .

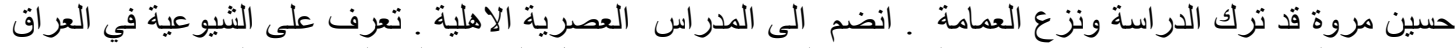

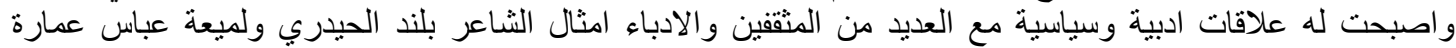

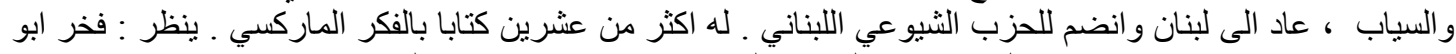

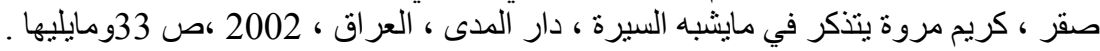

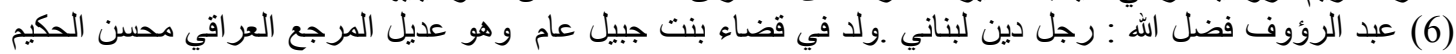

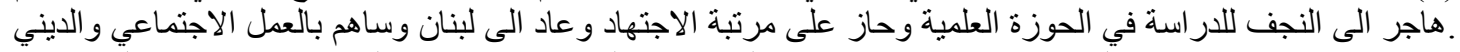

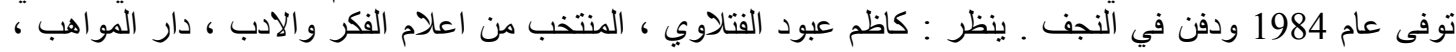

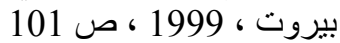
(7) محمد حسين فضل الله: رجل دين لبناني ـ ولد في النجف عام 1935 الثناء دراسة و الده في الحوزة العلمية فيها وانضم

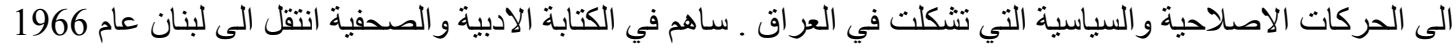

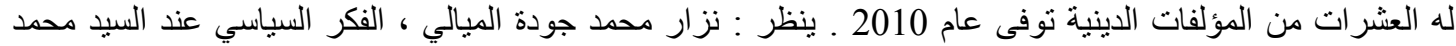

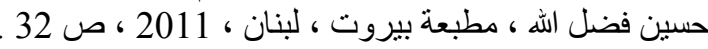

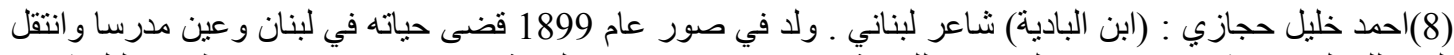

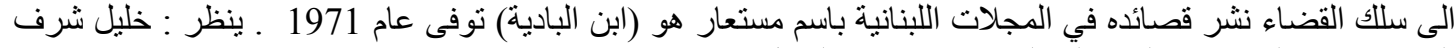
الدين ، تاريخ الزرارية والبلاد العاملية ، دار ومكتبة الهلال ، بيروت ، النيان ، 1995 ، ص 66 . 


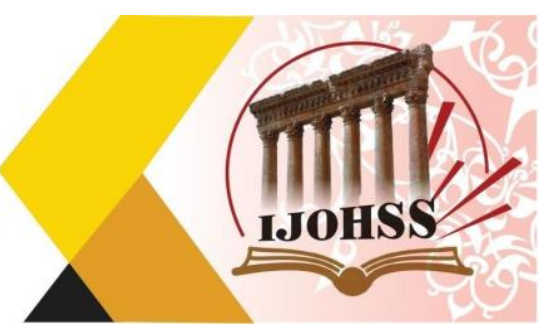

(9) محمد دكروب، من حسين مروة ، اوراق من سيرته وكلمات بمنزلة الوصية، مجلة النداء، (بيروت)، العدد 308، 24 (30)، 24

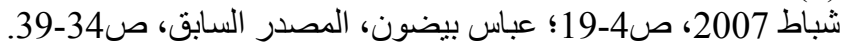

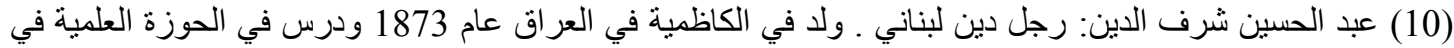

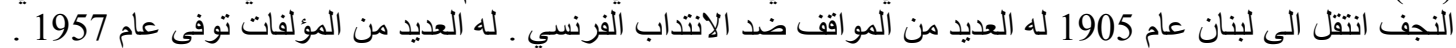

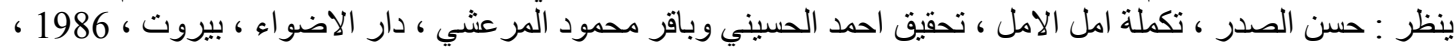
. 256

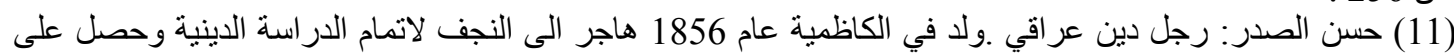

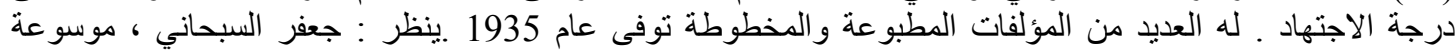

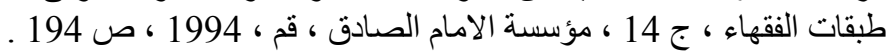

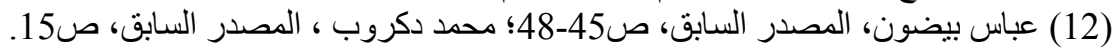

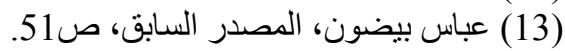

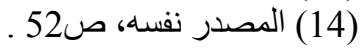

(15) محمد علي شرارة: اديب لبناني ـ ولا عام 1907 وسافر الى العراق عام 1920 للادراسة في الحوزة العلمية في

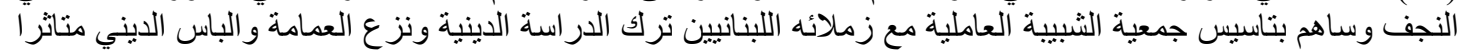

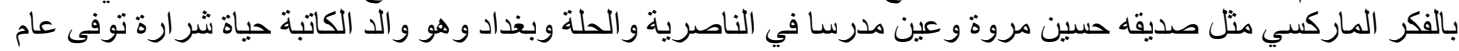
1979 ودفن في النجف ينظر :بلقيس شرارة ، محمد شرارة من الايمان الى حرية الفكر ، دار المدى ، بغداد ، 2009 ، 200 ص 50 ومايليها .

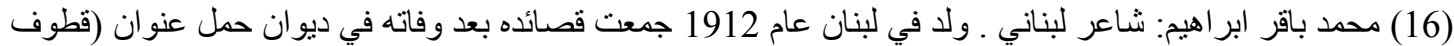

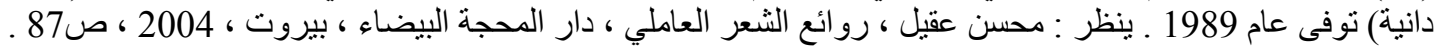

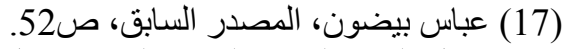
(18) حول الدور الفكري لمدينة النجف خلابل تلإلك المرحلة ينظر : محمد باقر احمد البهادلي، الحياة الفكرية في النجف

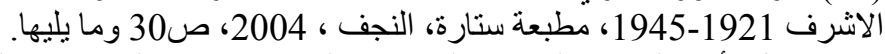

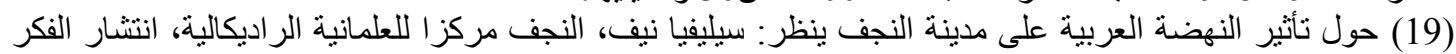

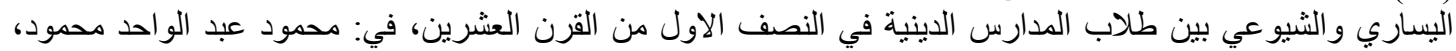

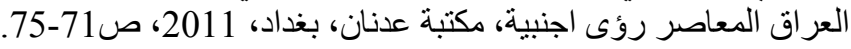
(20)Silia Naef ,the Arab shia and the Fascinaton with Communism :the Example of the life of Husayn Muruwwa (1910-1987), Asien Afrika Lateinamerika ,28, (2000),pp ,533-547 .

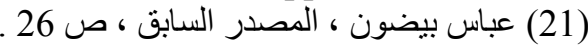

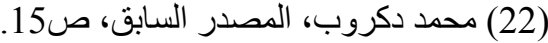

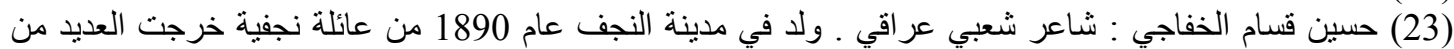

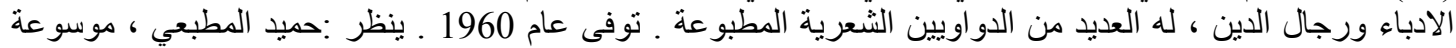

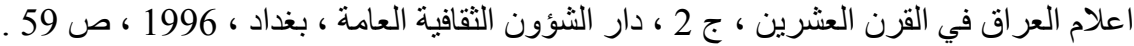
(24) محاضرة الدكتور صادق الطائي في الامسية الثقافية التي اقامتها مؤسسة الحوار التوار الانساني في لندن احتفاءا بالثاعر

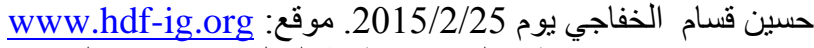

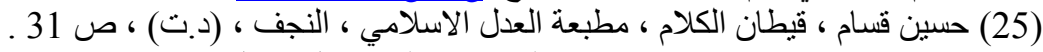

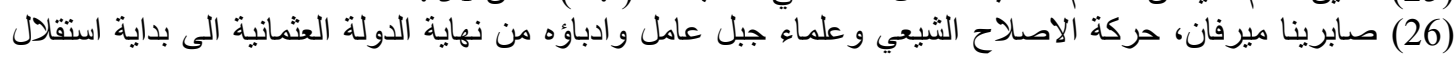

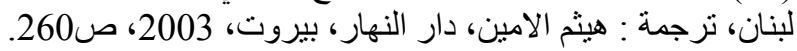

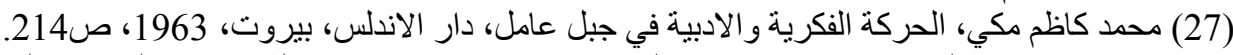

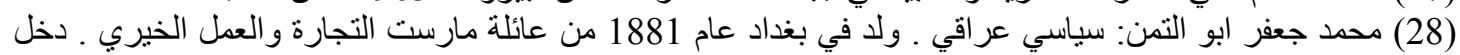

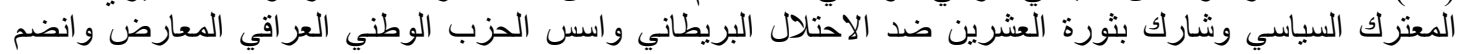

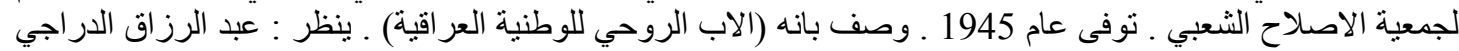

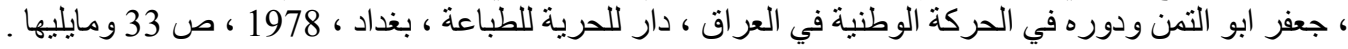
(29) عباس بيضون، المصدر السابق، صناكن. 


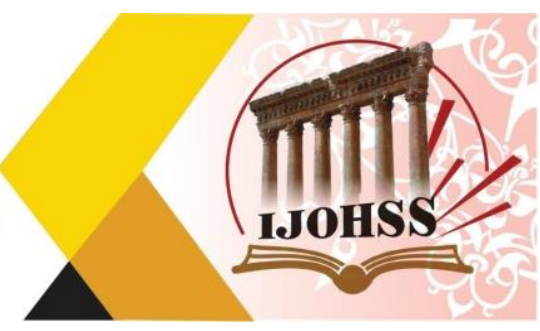

(30) محسن شرارة: رجل دين اصلاحي لبناني ـ ولد في لبنان عام 1901 و هاجر الى العراق للادراسة في الحوزة العلمية

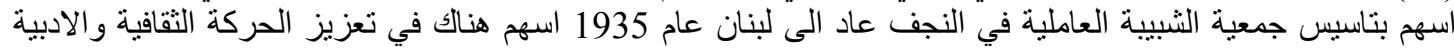

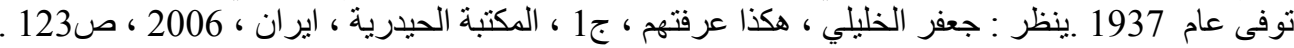

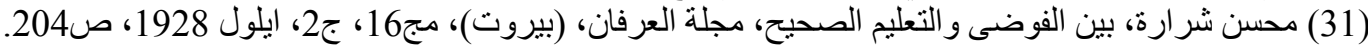

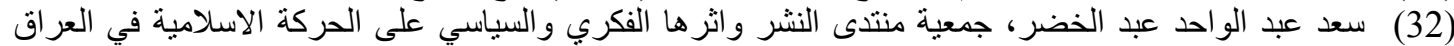

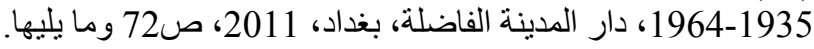

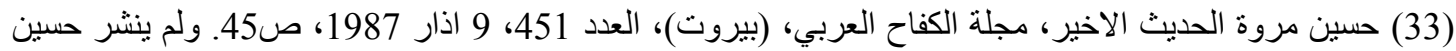

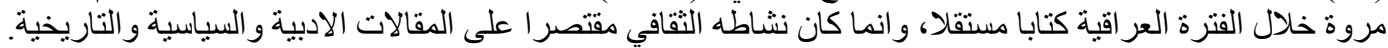

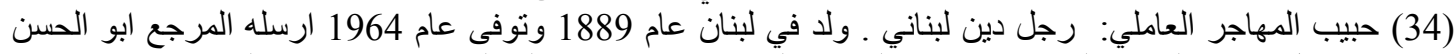

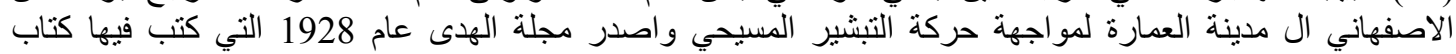

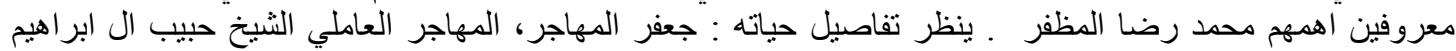

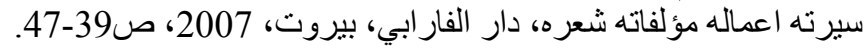

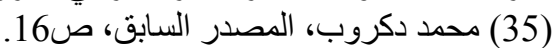

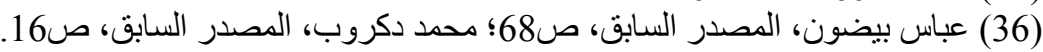

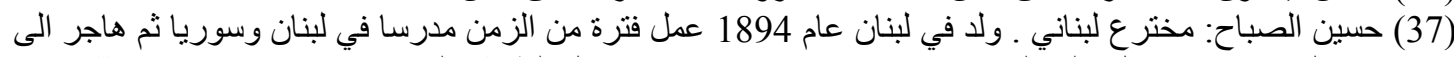

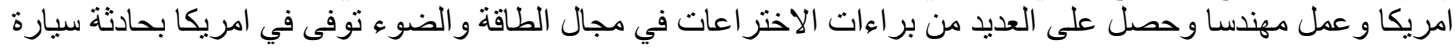

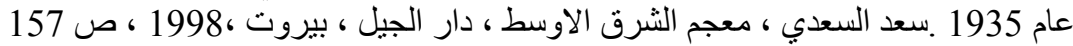

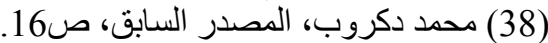

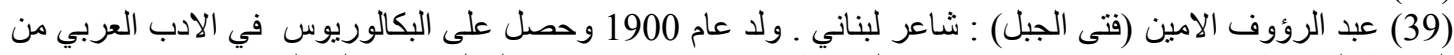

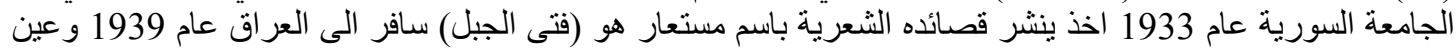

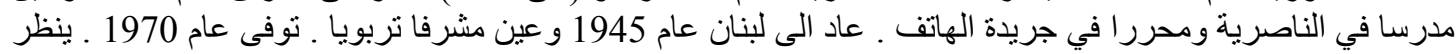

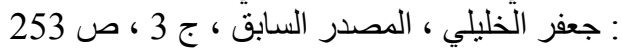

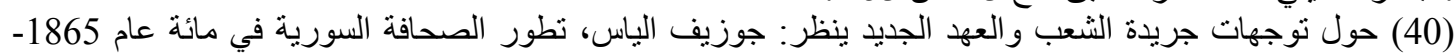

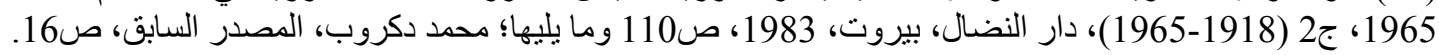

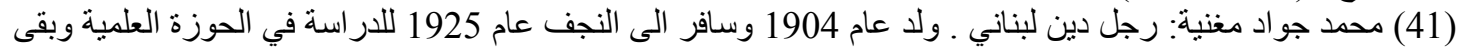

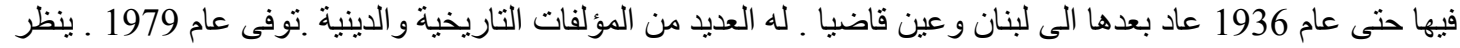

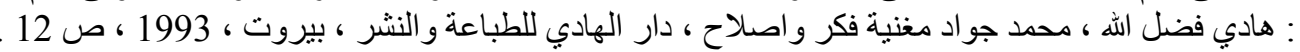

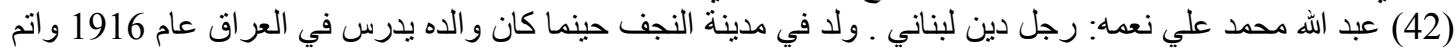

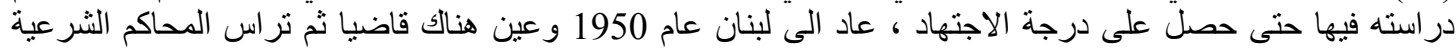

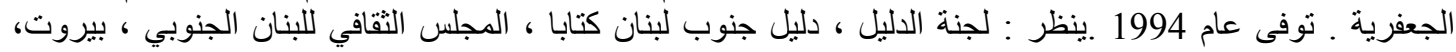

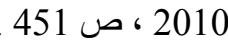
(43) محمد دكروب، المصدر السابق، ص14.

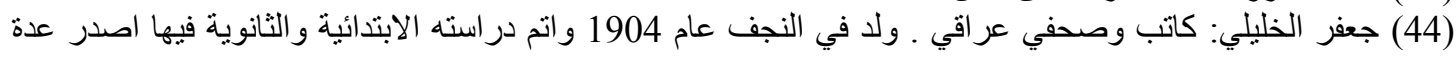

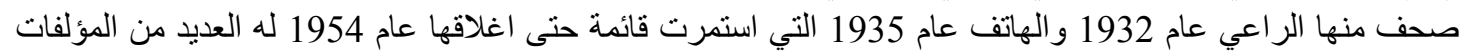

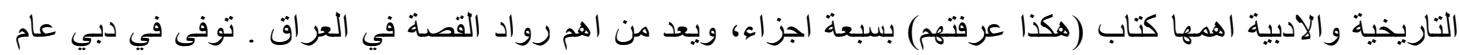

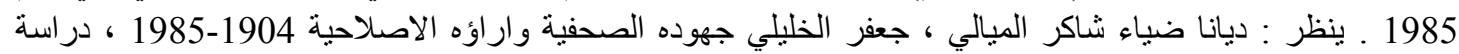

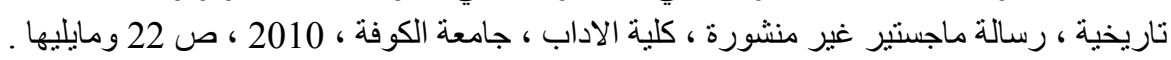

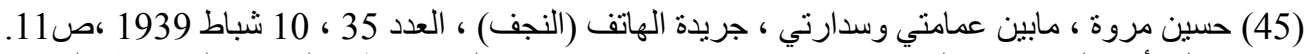

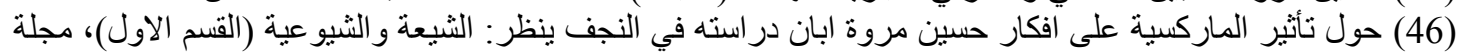

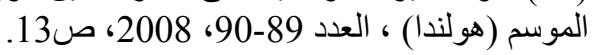

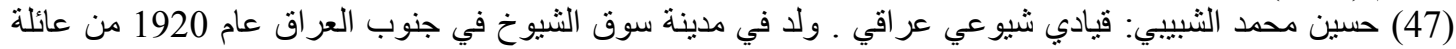

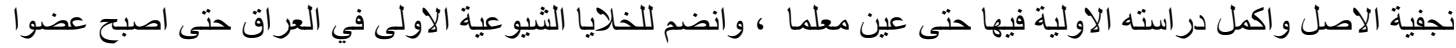

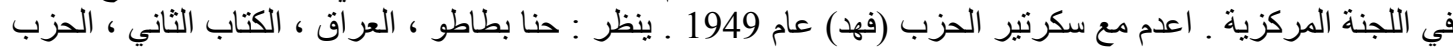

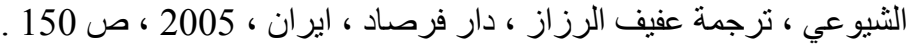




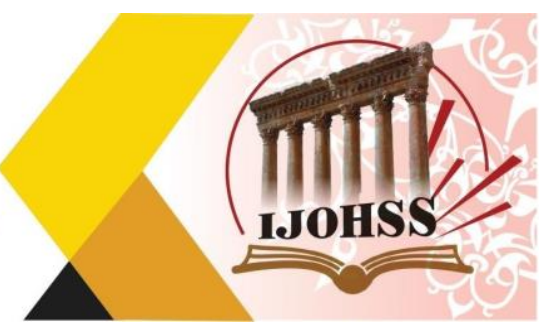

(48) حسين مروة، من النجف دخل حياتي ماركس، مجلة الطريق (بيروت)، العدد الثاني، السنة الثانبة والاربعين، شباط 1984، ص99؛ عبد الحسين شعبان، جذور التبار الديمقراطي في العراق، بيسان للنشر والتوزيع، بيروت، 2007،

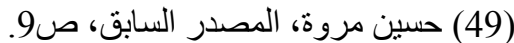
(50) كامل مروة، كارل ماركس و الاشتر اكية، مجلة العرفان، مج 23، ج2، مدر، تشرين الاول 1932، ص230.

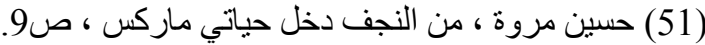

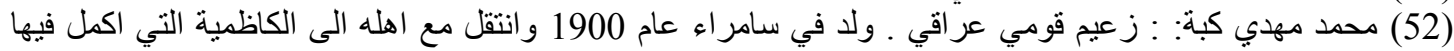

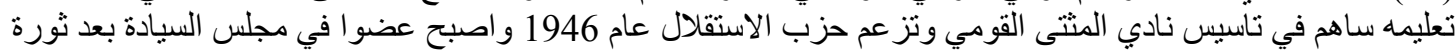

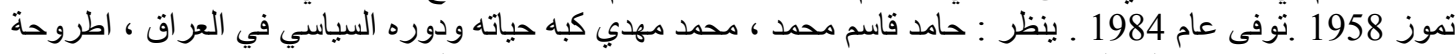

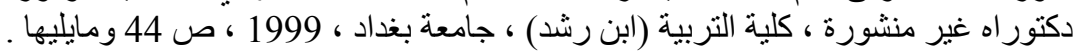

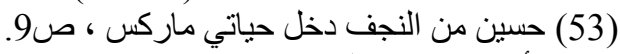

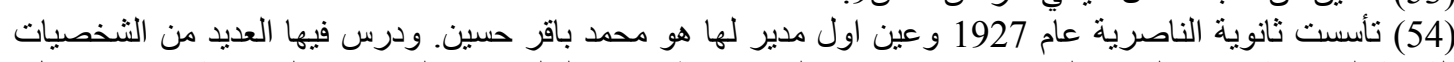

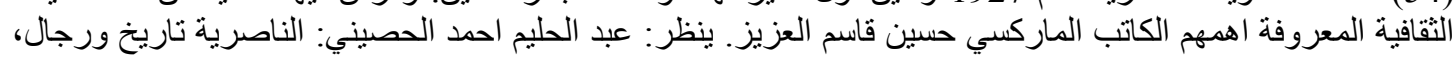

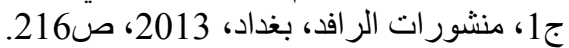

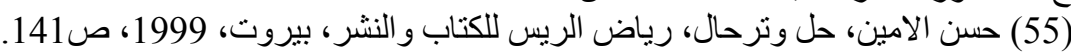

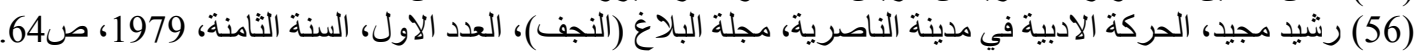

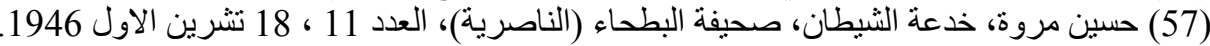

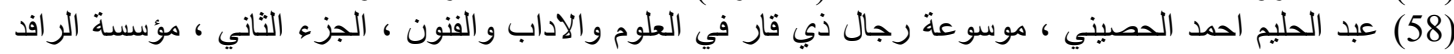

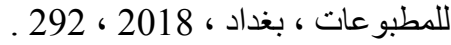

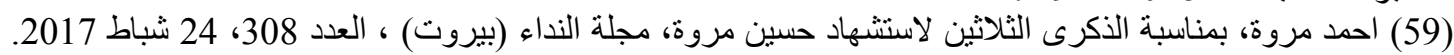

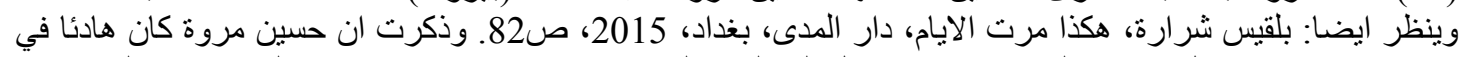

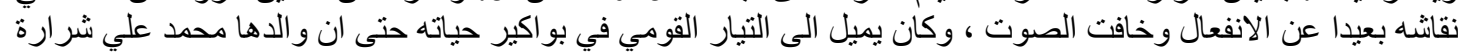
هو الذي اقنعا بالتحول نحو الافعول الفكر الماركسي.

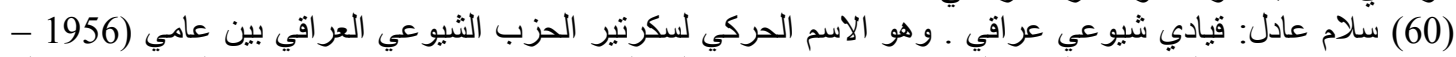

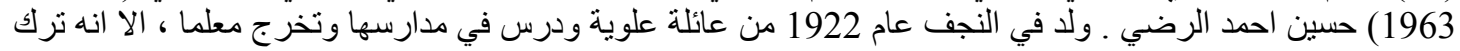

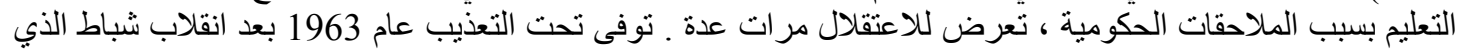

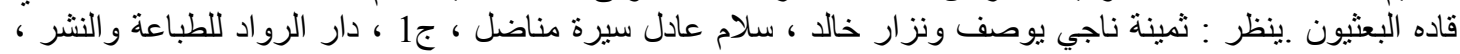

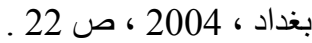
(61) نوفيق التميمي، شهادات عر اقية، حوارات في ذاكرة عر اقية، دار الحصاد، دمشق، 2011، ص238.

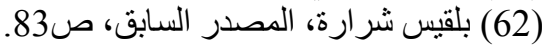
(63) حول مو اقفه السياسية خلال تلاك المرحلة ينظر : كريم مروة، الثيو عيون الاربعة الكبار في تاريخ لبنان الحديث، دار

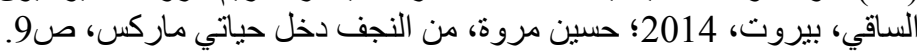
(64) طالب الحسن، بعث العراق من البداية المريبة حتى النهاية الغريبة، دار اور للطباعة والنشر، بيروت، 2011،

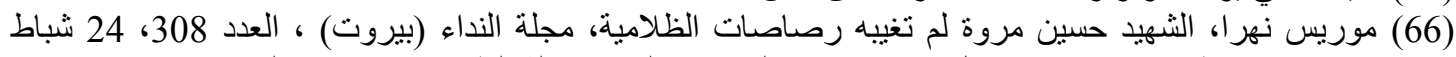

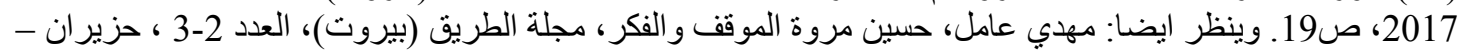
تموز، 1988.

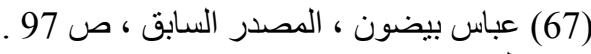

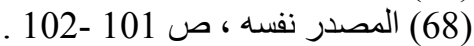

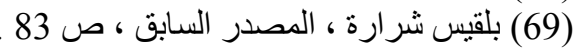
(70) صلاح الخرسان ، صفحات منات من تارخ العراق السياسي الحديث (الحركات الماركسية 1920-1990) ، مؤسسة

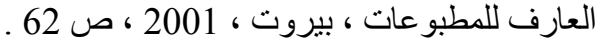




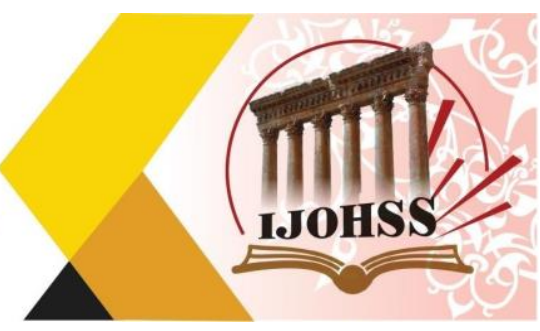

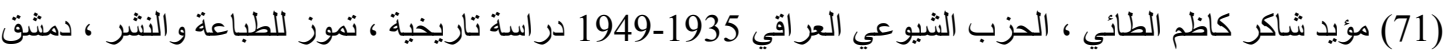

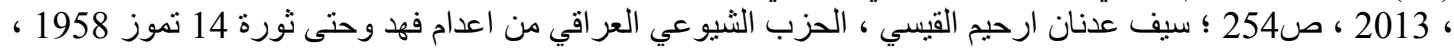

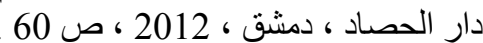

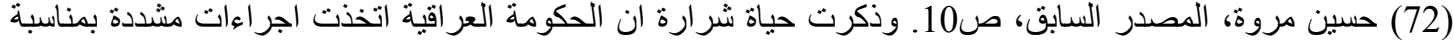

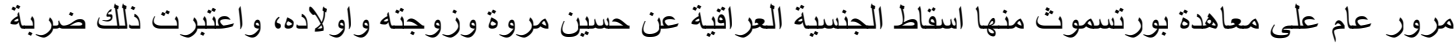

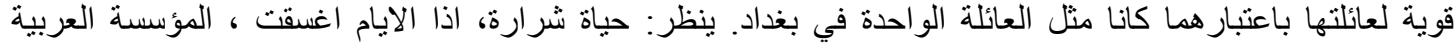

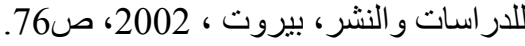

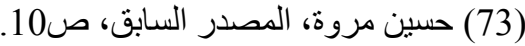

(74) حسين مروة ، النزعات المادية في الفلسفة العربية الاسلامية ، المجلد الاول ، دار الفارابي ، بيروت ، 2002 ، ص4

(75) كامل الجادرجي: سياسي عراقي ـ ولد في بغداد عام 1897 انتخب نائبا عن البرلمان العر اقي عام 1927 و انضم

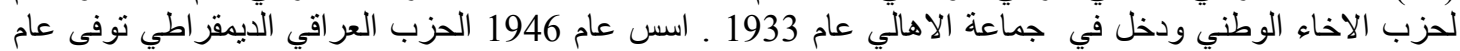

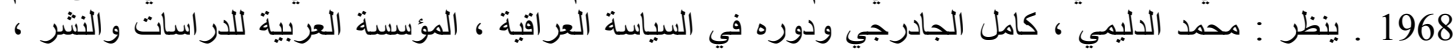

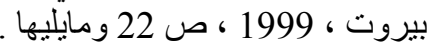

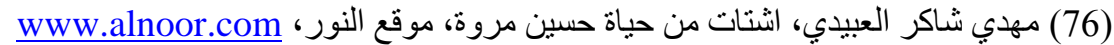

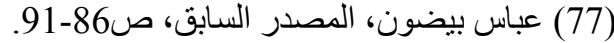

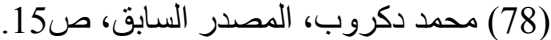

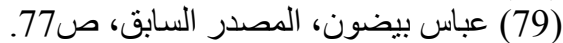

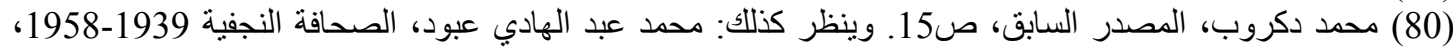

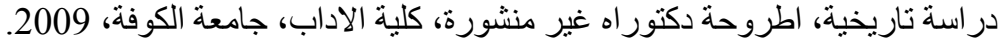

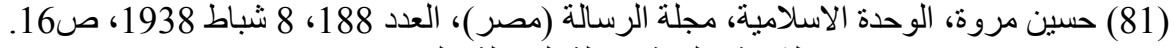

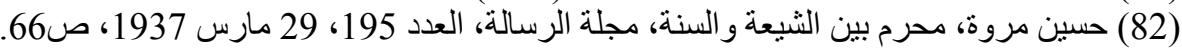

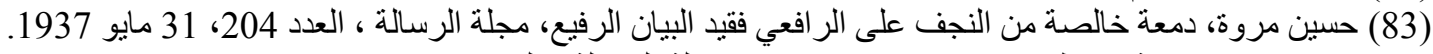

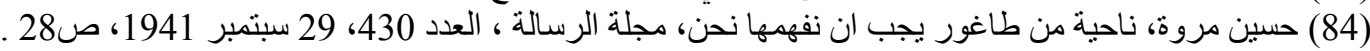

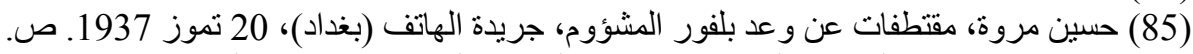

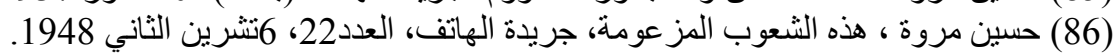

